\title{
TELEREHABILITATION IN THE MIDDLE EAST NORTH AFRICA REGION: A STRUCTURED REVIEW
}

\author{
NAIF QASAM ALJABRI, OT, MSC ${ }^{1,2}$, KIM BULKELEY, OT, PHD, ANNE CUSICK, OT, \\ $\mathrm{PHD}^{1}$
}

${ }^{1}$ FACULTY OF MEDICINE AND HEALTH, THE UNIVERSITY OF SYDNEY, AUSTRALIA

${ }^{2}$ COLLEGE OF MEDICAL REHABILITATION SCIENCES, TAIBAH UNIVERSITY, SAUDI ARABIA

\begin{abstract}
A structured review using the PRISMA guidelines, MeSH keywords and eight health databases was conducted (1990 to March 2021). Telerehabilitation research evidence from the Middle East and North Africa region (MENA) was summarized. Twelve studies from Iran, Israel, Morocco, and Saudi Arabia met inclusion criteria; nearly all had been published within the past five years. Methodological quality was moderate to good in the four randomized controlled trials, five cohort-studies and three cross-section surveys. There were seven intervention studies in cardiovascular, musculoskeletal, neurology or burn rehabilitation and three patient perception and two practitioner perception studies. Narrative synthesis revealed content themes relating to rehabilitation availability and accessibility; patient/practitioner perceptions of telerehabilitation; telerehabilitation to augment traditional services; and barriers to telerehabilitation. Telerehabilitation practice in MENA has been demonstrated as feasible, acceptable to patients, and effective in practitioner-designed cohort specific programs. Practitioners are generally positive but lack experience and need training, enabling technological systems, and policy frameworks.
\end{abstract}

Keywords: Middle East, Northern Africa, Rehabilitation, Telerehabilitation

Rehabilitation is an integral part of health systems, supporting people who have or are at risk of having disability to maximise their ability to engage in everyday activities and fully participate in their life situations (World Health Organization [WHO], 2017; WHO, 2020). Rehabilitation is provided within a continuum of care from hospital care to rehabilitation in the community (Stucki, Cieza \& Melvin, 2007). It includes interventions for preventing impairment and deterioration in the acute phase of care and optimization and maintenance of functioning in the post-acute long-term phases of care (Meyer et al., 2011; Stucki, Rinehardt \& Grimby, 2007). The "World Report on Disability" identifies unmet rehabilitation needs across the globe (WHO, 2011), there is an increasing demand for rehabilitation (WHO, 2020), and variable status of rehabilitation as an essential health service (WHO, 2018), particularly in the developing world (WHO, 2011, 2017). This is concerning because the majority of people with disability (80\%) live in developing countries (WHO, 2011).

One region where rehabilitation access and availability are problematic is the Middle East North Africa region, also known as MENA (Human Rights Watch, 2014). There are 19 countries in this region and all but one (Israel) is classified by the United Nations as being in 'developing regions' (United Nations Statistical Division, 2020). According to the classification used by Human Rights Watch (2020), the countries in MENA are: Algeria, Bahrain, Egypt, Iran, Iraq, Israel/Palestine, Jordan, Kuwait, Lebanon, Libya, Mauritania, Morocco/Western Sahara, Oman, Qatar, Saudi Arabia, Syria, Tunisia, the United Arab Emirates, and Yemen. Currently, there are no aggregate disability prevalence data for MENA countries, however, individual country estimates, using various metrics, range up to 20\% (Barlev et al., 2015; Thompson, 2017; United Nations Economic and Social Commission for Western Asia, 2018). There is also no comprehensive data regarding the mix of public, private, or not-for-profit disability and/or rehabilitation services available across the MENA region (Benjadid, 2019; Cusick, \& Hamed El Sahly, 2018; Rosen, Waitzberg \& Merkur, 2015). Historically, rehabilitation has been a low priority (WHO, 2019). Barriers to rehabilitation access and availability in low and middle-income countries include poor availability, access issues such as service location and transport problems, individuals not being aware of the services that do exist, lack of specialised equipment and/or assistive devices, and the cost of services (Bright, Wallace \& Kuper, 2018; WHO, 2011; Zahid et al., 2017). Other problems include rehabilitation workforce shortages and limited skills of rehabilitation providers leading to access and quality issues (Benjadid, 2019; Bright et al., 2018; Cusick, \& Hamed El Sahly, 2018; WHO, 2011).

Telerehabilitation has been proposed as an alternative to in-person consultation to provide rehabilitation (Laver et al., 2020). Telerehabilitation is the delivery of rehabilitation services using information and communication technologies (Hung \& Fong, 2019; McCue, Fairman \& Pramuka, 2010; Molini-Avejonas et al., 2015; Nafai, Barlow \& Stevens-Nafai, 2017). By using technologies such as telephone, videophone, videoconferencing, webcams, web apps, online networks, virtual reality, and 
wearable technology solutions (McCue et al., 2010; Molini-Avejonas et al., 2015; Peretti et al., 2017), people needing rehabilitation services can communicate with professionals or rehabilitation teams and receive consultation and interventions. Sites for telerehabilitation services can include homes, clinics, schools, residential care homes, and other community facilities (Piron et al., 2008; Schutte et al., 2012). Using such technology for remote delivery of services can make rehabilitation more accessible and available (Brennan, Mawson \& Brownsell, 2009; Peretti et al., 2017), assisting patients to overcome barriers to program participation (Peretti et al., 2017; Tenforde et al., 2017).

In MENA countries where rehabilitation services are limited in number, concentrated in few locations, poorly interconnected, or with challenges in transport infrastructure and limited community facilities, telerehabilitation may provide a service delivery model with the potential to increase access and capacity. Telerehabilitation processes can include patient consultation, assessment, monitoring, intervention, supervision, and education (Brennan et al., 2009, 2011; Sarsak, 2020). The body of evidence for impact, effectiveness, and cost-effectiveness in different diagnostic groups and with different interventions is still emerging, but promising (Agostini et al., 2015; Hung \& Fong, 2019; Laver et al., 2020; Mclntyre, Robinson \& Mayo, 2020; Sarfo et al., 2018; Torsney, 2003). Investigation into the extent of telerehabilitation in MENA is yet to occur, and to date there has been no review of research into this topic, but there are indications of practice interest. Telerehabilitation has, for example, been recommended in MENA, as a rehabilitation delivery approach in Morocco (Nafai et al., 2017), and as an alternative to in-person consultation during the COVID-19 pandemic (Abolghasemian et al., 2020; Qureshi et al., 2021; Ziadé et al., 2020).

This emerging practice comes off-the-back of a longstanding interest in technology-enabled remote health service delivery in MENA. The earliest evidence of e-health use in MENA is in the "Handbook of Telemedicine" (Ferrer- Roca \& Sosa Ludicissa, 1999), where installation of internet-based consultation capacity is reported in the King Faisal Specialist Hospital in Saudi Arabia (https://www.kfshrc.edu.sa/en/home). More recently, the World Health Organisation Global Surveys on eHealth (WHO, 2010, 2016) show a slow but upward trajectory in e-health services in the region. The second survey (WHO, 2010) identified that Jordan, Bahrain, Algeria, Israel, and Oman were offering e-health services, while in the third survey Morocco and Mauritania were reported to be undertaking testing and review processes prior to e-health implementation (WHO, 2016, 2017). In addition, country-specific initiatives planning for e-health services are underway; Saudi Arabia for example, has developed national strategic plans for e-health (Ministry of Health, 2013). Building on this momentum, this study aims to identify, summarize and synthesize research relating to telerehabilitation in the MENA region.

\section{METHODS}

A structured literature review was implemented. The review identified the research question, developed a search strategy to access relevant sources, performed study selection, extracted and recorded data; and collated and summarised the results. PRISMA (Page et al., 2021) guidelines were used to report the study method and findings.

A search strategy was developed in consultation with a health sciences librarian using a combination of keywords and medical subject headings (MeSH) terms (Table 1). Eight healthcare databases were used: the Allied and Complementary Medicine Database (AMED), the Cumulative Index to Nursing and Allied Health Literature (CINAHL), the Cochrane Database of Systematic Reviews (CDSR), Excerpta Medica Database (EMBASE), the Joanna Briggs Institute (JBI) EBP Database, Medline, Scopus, and Web of Science (WoS). The databases were searched from January 1990 through December 2020 with an update search covering the period January 2021 through March 2021. The full search strategy for each database is presented in the Appendix.

Table 1

Search Strategy

(1) Telehealth OR tele-health OR telemedicine OR tele-medicine OR telerehabilitation OR tele-rehabilitation OR ehealth OR e-health OR mobile health OR mhealth AND

(2) Rehabilitation OR habilitation AND

(3) Middle East OR Bahrain OR Qatar OR United Arab Emirates OR Yemen OR Iran OR Iraq OR Israel OR Jordan OR Kuwait OR Lebanon OR Oman OR Syria OR Saudi Arabia OR Palestine OR North Africa OR Tunisia OR Egypt OR Morocco OR Western Sahara OR Algeria OR Libya OR Mauritania.

Note. In the Human Rights Watch list, the following countries are paired names but have been separated here with OR as paired names are not consistently used in controlled vocabulary indexes: Palestine/lsrael and Morocco/Western Sahara. 
The first author (NA) located and downloaded all sources into the reference management software Endnote $\mathrm{x} 9^{\mathrm{TM}}$ where identification and removal of any duplicate studies was completed. The data were exported to an Excel ${ }^{\mathrm{TM}}$ spreadsheet noting $^{\mathrm{T}}$ author(s), year of publication, title, abstract, and publication type. The first and last author (NA and AC) independently screened titles and abstracts of all studies to ascertain whether or not inclusion criteria were met (Table 2). It was agreed from the outset that any rating differences would be resolved through consensus-based discussions which involved the second author $(K B)$. A full text version of each screened source $(n=15)$ were independently assessed by NA and AC to determine if inclusion criteria were met. Three papers were excluded following full text review (Figure 1).

Table 2

\section{Study Inclusion and Exclusion Criteria}

\begin{tabular}{|c|c|}
\hline Inclusion criteria & Exclusion criteria \\
\hline $\begin{array}{l}\text { The study collected original data using experimental or } \\
\text { observational, survey or qualitative research designs. }\end{array}$ & $\begin{array}{l}\text { Review articles, books, conference abstracts, } \\
\text { magazine articles, editorials, perspectives and opinion } \\
\text { articles, study protocols, commentaries, policies, } \\
\text { guidelines, and reports }\end{array}$ \\
\hline $\begin{array}{l}\text { An approach was explored that met the definition of } \\
\text { telerehabilitation provided by McCue, Fairman \& } \\
\text { Pramuka (2010): the delivery of rehabilitation services } \\
\text { that use a range of information and communication } \\
\text { technologies to serve patients, clinicians, and } \\
\text { systems. }\end{array}$ & $\begin{array}{l}\text { Any health services that did not meet the definition of } \\
\text { telerehabilitation }\end{array}$ \\
\hline $\begin{array}{l}\text { The study focused on rehabilitation services provided } \\
\text { or any medical conditions by at least one of the } \\
\text { following rehabilitation professionals: rehabilitation } \\
\text { physician, occupational therapist, physiotherapist, } \\
\text { speech-language pathologist, psychologist, } \\
\text { audiologist, exercise therapist, rehabilitation counsellor } \\
\text { or rehabilitation nurse. }\end{array}$ & $\begin{array}{l}\text { The study focused on health services provided by any } \\
\text { health professionals who are not indicated as having a } \\
\text { focus on rehabilitation. }\end{array}$ \\
\hline $\begin{array}{l}\text { Original data could be from patients or from } \\
\text { rehabilitation professionals. }\end{array}$ & $\begin{array}{l}\text { No original data and/or data that is not from patients or } \\
\text { rehabilitation professionals. }\end{array}$ \\
\hline The full text study was written in English language. & The full text study was not written in English language. \\
\hline $\begin{array}{l}\text { The study was conducted in MENA countries as } \\
\text { classified by the Human Rights Watch. }\end{array}$ & $\begin{array}{l}\text { The study's topics have not specified MENA countries, } \\
\text { as classified by Human Rights Watch. }\end{array}$ \\
\hline $\begin{array}{l}\text { Article was published in a peer-reviewed journal as } \\
\text { indicated by (a) Ulrichsweb }{ }^{\mathrm{TM}} \text { or (b) self-report } \\
\text { information from journal's homepage (taken in good } \\
\text { faith). }\end{array}$ & $\begin{array}{l}\text { No evidence that the article was published in peer } \\
\text { reviewed journal. }\end{array}$ \\
\hline
\end{tabular}


Figure 1

PRISMA Flow Diagram

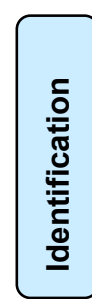

\begin{tabular}{|c|c|c|c|c|c|c|c|}
\hline & \multirow{2}{*}{\multicolumn{3}{|c|}{105 records identified from 8 databases }} & \\
\hline & & & & & & & \\
\hline AMED & CINAHL & EMBASE & $\frac{1}{\text { MEDLINE }}$ & & Brigg & \begin{tabular}{|l} 
Scopus \\
\end{tabular} & Web of Science \\
\hline$(n=2)$ & $(n=17)$ & $(n=24)$ & $(n=6)$ & Systematic Reviews $(n=0)$ & EBP Database $(n=0)$ & $(n=36)$ & $(n=20)$ \\
\hline
\end{tabular}

\section{Identification}
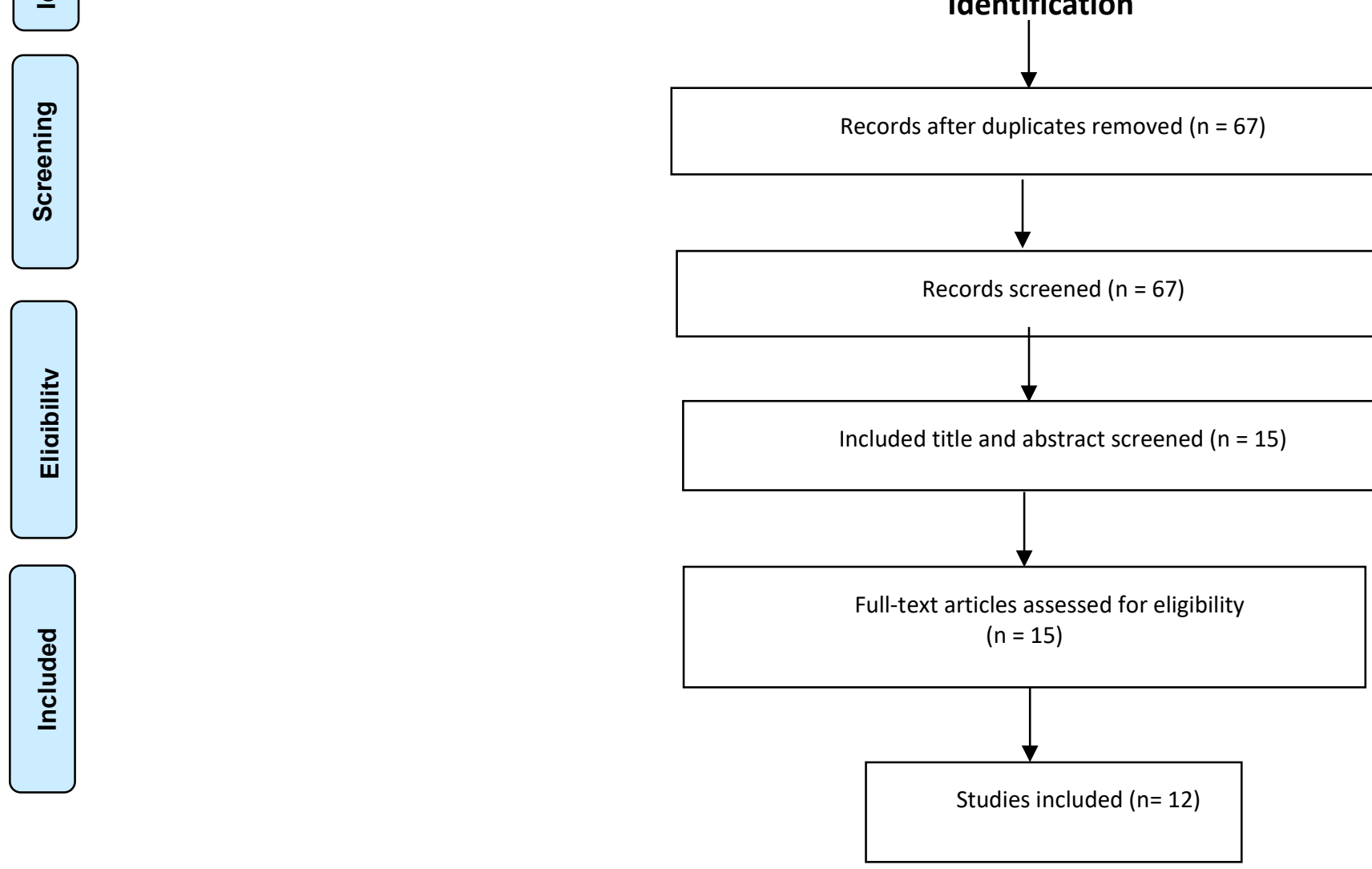

Duplicate records removed $(n=38)$

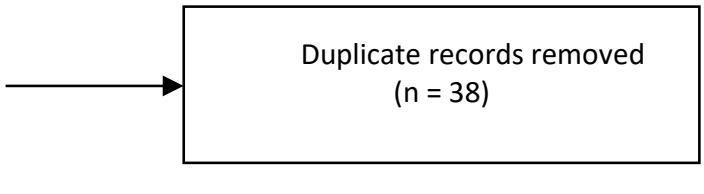

(n)

Records excluded

$(n=52)$

Full-text articles excluded

$(n=3)$

Not eligible to inclusion criteria 
The sources $(n=12)$ meeting inclusion criteria had data extracted and entered into an Excel ${ }^{\mathrm{TM}}$ spreadsheet by NA and independently cross-checked by AC. Data extracted were: author(s), publication year, title of the study, title of the journal, journal peer review status, study location, study aim, research design used, participant attributes (sample size, age data, gender, whether patients or rehabilitation professionals, types of rehabilitation professionals), name and brief description of intervention (if one was used), outcome measures, type of telerehabilitation platform/modality, telerehabilitation health professional providers and key findings. This data was extracted because individually and cumulatively they characterised what was known about telerehabilitation in MENA in published research.

Three critical appraisal tools were used to assess methodological quality and risk of bias; each matched the study design of included studies. Two reviewers (NA and AC) conducted the appraisals, and consensus decisions were reached regarding each checklist item. To enable aggregate description of methodological quality, the authors developed a cumulative level of attainment for each checklist to indicate whether the paper was poor ( $<50 \%$ of included checklist items were demonstrated), moderate (50- $80 \%$ demonstrated), or good (> $80 \%$ demonstrated). The relative attainment for each grade of attainment was modelled on that used in Reilly et al. (2016). Ratings for each study are presented in Table 3. Individual appraisals are available on request. The following critical appraisal tools were used:

- The Critical Appraisal Skills Programme checklist for randomized controlled trials (Critical Appraisal Skills Programme, 2020). All questions for assessing methodological quality were included; two questions relating to the local application were excluded.

- The Critical Appraisal Skills Programme checklist for cohort studies (Critical Appraisal Skills Programme, 2018). All questions for assessing methodological quality were included except number 7 which was excluded because it is a summary question about reported results and did not have a rating scale response. Question number 8 was modified to include the rating scale of 'Yes, No, and Can't Tell', the same as questions 1-6. To answer 'Yes,' the research needed to report point and interval estimates appropriate for descriptive and inferential results; three questions relating to local application were excluded.

- The Joanna Briggs Institute (JBI) checklist for Studies Reporting Prevalence Data was used for cross-sectional studies (The Joanna Briggs Institute, 2013). This contains nine questions, and all were used.

To provide a narrative synthesis of findings, the text content of each source was considered using thematic analysis. NVivo 12 plus $^{\mathrm{TM}}$ software (QSR International, 2020) was used to extract text data and provide the platform for content analysis to create themes and subthemes closely aligned with the data. A consensus approach was taken by the research team to enable theme development using keywords and phrases informed by literature reviewed in the introduction.

\section{RESULTS}

Twelve articles published in English met the inclusion criteria. The articles' years of publication ranged from 2015 to 2020 (mode 2020, 2018). Four of 19 MENA countries produced research: Iran $(n=2)$, Israel $(n=5)$, Morocco $(n=1)$, and Saudi Arabia $(n=4)$. There were 10 studies involving patients and two sampled health professionals. There were four randomised controlled trials and five cohort studies (four prospective, one retrospective). Three studies employed cross-sectional surveys. Methodological quality was rated moderate-to-good for all studies.

Patient studies were conducted in Israel $(n=5)$, Iran $(n=2)$, Morocco $(n=1)$ and Saudi Arabia $(n=2)$. A total of 621 patients were involved (sample size ranged from 12 to 200; mean 62.1). All patients were community-dwelling adults, with an age range of 18 to 85 years. Most required physical rehabilitation for musculoskeletal disorders, burns, and cardiovascular conditions (excluding stroke) (Table 3). One study was about neurorehabilitation with participants having conditions including acquired brain injury and multiple sclerosis (Kizony et al., 2017).

Seven studies examined intervention impact (Table 3). Interventions were provided by occupational therapists (Golebowicz et al., 2015), physiotherapists (Alasfour \& Almarwani, 2020; Kalron et al., 2018), occupational therapists and/or physiotherapists (Kizony et al., 2017), rehabilitation physician (Azma et al., 2018) and multidisciplinary rehabilitation teams (Kargar et al., 2020; Nabutovsky, Ashri et al., 2020). Rehabilitation program goals were predominantly directed toward decreasing impairment (Alasfour \& Almarwani, 2020; Azma et al., 2018; Golebowicz et al., 2015; Kalron et al., 2018; Kizony et al., 2017; Nabutovsky, Ashri et al., 2020b) or enhancing quality of life (Kargar et al., 2020). Telerehabilitation delivery modalities included: computer-based software (Golebowicz et al., 2015; Kalron et al., 2018; Kizony et al., 2017), phone (Azma et al., 2018), and phone 'apps' (Alasfour \& Almarwani, 2020; Kargar et al.,2020; Nabutovsky, Ashri et al., 2020b). 
Three studies explored patient perceptions of telerehabilitation (Alqahtani, 2019; Bonnechère et al., 2017; Nabutovsky, Nachschon et al., 2020) and two investigated the perceptions of rehabilitation professionals (Aloyuni et al., 2020; Ullah et al., 2020). The patient studies used different settings. In Saudi Arabia patients came from home health care settings where physiotherapy was delivered using telerehabilitation (Alqahtani, 2019). In Morocco there was clinic and at home use of online game technology for physiotherapy exercise practice (Bonnechère et al., 2017), and in Israel post-hip surgery telerehabilitation was conducted at home (Kalron et al., 2018). Professionals who shared perceptions all came from Saudi Arabia. In one study (Aloyuni et al., 2020), a national survey of physiotherapists revealed attitudes towards telerehabilitation practice. In the other study a multidisciplinary sample of rehabilitation professionals from physical medicine and rehabilitation doctors, orthotist/prosthetist, physiotherapists, psychologists, occupational therapists, speech-language pathologists, and rehabilitation nurses described their knowledge, acceptance, use and perceived risks of telerehabilitation (Ullah et al., 2020).

All intervention studies and studies about patient perceptions used standardized instruments to collect data on one or more variables; the names of the instruments are listed in Table 3. There was no consistency in instrumentation use because each study aimed to answer a different intervention question. The two professional perception studies used author-designed self-report surveys. The only standardized instrument that was specifically designed to ascertain views about the delivery of service by information technologies was the Telehealth Usability Questionnaire, (TUQ) developed by Parmanto et al. (2016), cited by Langbecker et al. (2017) and used in the Alqahtani (2019) study.

While an inspection of Table 3 reveals all telerehabilitation interventions achieved statistically significant improvements in primary outcomes, the intervention questions, study designs and impact measures were too variable to permit a meta-analysis of findings.

Narrative synthesis was performed by analysing article content and identifying common concept categories, which were then iteratively grouped first into subthemes and then into four themes. All 12 sources were included in this synthesis. Four themes were evident: (1) rehabilitation availability and accessibility, (2) perceptions of telerehabilitation, (3) telerehabilitation to augment traditional rehabilitation services, and (4) barriers to telerehabilitation. Each of these is now described.

\section{THEME 1: REHABILITATION AVAILABILITY AND ACCESSIBILITY}

This theme captures the remarkable lack of, or restricted access to rehabilitation services in MENA. The limited access to rehabilitative care services was particularly evident in remote areas (Bonnechère et al., 2017; Ullah et al., 2020). Services were more available in urban areas than in rural areas (Aloyuni et al., 2020; Ullah et al., 2020). Some participants had to travel to obtain the rehabilitation services they required in major cities (Aloyuni et al., 2020; Ullah et al., 2020). Due to the COVID-19 outbreak, access to rehabilitation services were restricted (Aloyuni et al., 2020). A shortage of rehabilitation professionals was also identified (Bonnechère et al., 2017; Ullah et al., 2020).

There were obstacles to rehabilitation service availability and access. After completion of a patient's hospital healthcare and their discharge, there was a lack of continuity of rehabilitative care due to non-adherence and a lack of community-based rehabilitation programs (Ullah et al., 2020). Poor adherence to traditional rehabilitative services among patients occurred due to distance from rehabilitation services, job demands (Golebowicz et al., 2015; Kalron et al., 2018; Nabutovsky, Ashri et al., 2020), time constraints, transportation issues (Alasfour \& Almarwani, 2020; Alqahtani, 2019; Nabutovsky, Ashri et al., 2020), family/household responsibilities, commitments and social duties (Alasfour \& Almarwani, 2020; Alqahtani, 2019), and personal beliefs and habits (Bonnechère et al., 2017).

\section{THEME 2: PERCEPTIONS OF TELEREHABILITATION}

This theme revealed perceptions of patients and practitioners about using various forms of telerehabilitation. Patientparticipants in a telerehabilitation intervention study indicated they were satisfied with and comfortable using telerehabilitation software technologies (Alqahtani, 2019; Bonnechère et al., 2017; Kizony et al., 2017).

In one cross-sectional study, most patients were willing to undergo rehabilitation follow-ups and therapeutic communication by phone (Nabutovsky, Nachschon et al., 2020a). The phone is a frequently used method for telerehabilitation; is user-friendly due to the variety of call features or apps (Alasfour \& Almarwani, 2020; Azma et al., 2018; Kargar et al., 2020; Nabutovsky, Ashri et al., 2020); and is also attractive to more elderly patients (Azma et al., 2018). 
Studies by Aloyuni et al (2020) and Ullah et al (2020) reported that the majority of rehabilitation professionals regarded telerehabilitation as a valuable way to deliver rehabilitation services despite the fact that most of them did not use it in their practice.

\section{THEME 3: TELEREHABILITATION TO AUGMENT TRADITIONAL REHABILITATION SERVICES}

Across the studies, telerehabilitation was reported as a service provided in addition to typical rehabilitation care. It was reported as having effective results as compared to conventional care sessions (Alasfour \& Almarwani, 2020; Kalron et al., 2018; Kargar et al., 2020). Telerehabilitation was also suggested to have the potential to decrease hospital admissions and length of hospital stay (Azma et al., 2018; Kalron et al., 2018).

Telerehabilitation enabled continuing rehabilitation care after hospital discharge and follow-up (Alasfour \& Almarwani, 2020; Kalron et al., 2018; Kizony et al., 2017; Kargar et al., 2020; Ullah et al., 2020), which improved quality of life and outcomes (Kargar et al., 2020; Ullah et al., 2020). It also increased engagement with rehabilitation services remotely compared to traditional services (Alasfour \& Almarwani, 2020; Kalron et al., 2018) and demonstrated good adherence (Nabutovsky, Ashri et al., 2020).

Participation rate in rehabilitation services was good with telerehabilitation. Telerehabilitation gave an alternative option to hospital or clinic-based service (Nabutovsky, Ashri et al., 2020) and permitted collaboration with rehabilitation professionals (Kizony et al., 2017), therapeutic relationships (Kargar et al., 2020) and person-centered care (Nabutovsky, Nachschon et al., 2020). Telerehabilitation services attracted good patient satisfaction (Nabutovsky, Ashri et al., 2020) and remote sessions with the same therapist who provides the in-person sessions increases patient satisfaction and confidence (Alqahtani, 2019).

Telerehabilitation helped to facilitate remote access to rehabilitation services (Alasfour \& Almarwani, 2020; Alqahtani, 2019; Aloyuni et al., 2020; Azma et al., 2018; Bonnechère et al., 2017; Golebowicz et al, 2015; Kalron et al., 2018; Nabutovsky, Ashri et al., 2020), especially for patients who could or would not attend in-person rehabilitation sessions (Alasfour \& Almarwani, 2020; Azma et al., 2018; Alqahtani, 2019; Nabutovsky, Nachschon et al., 2020), and/or whose physical presence in the clinic was not required (Kalron et al., 2018).

Due to the COVID-19 lockdown and the required social distancing, telerehabilitation was identified to be the best approach to deliver rehabilitation services and avoid infection (Aloyuni et al., 2020).

Telerehabilitation helped to reduce treatment expenses compared to traditional rehabilitation (Azma et al., 2018; Golebowicz et al., 2015; Kargar et al., 2020). The use of telerehabilitation saved time and reduced absences from work for patients (Alasfour \& Almarwani, 2020; Alqahtani, 2019; Azma et al., 2018; Golebowicz et al., 2015; Nabutovsky, Ashri et al., 2020), and their supporting relatives (Alqahtani, 2019).

Finally, telerehabilitation use addressed the shortage of providers and inadequate public health service infrastructure (Bonnechère et al., 2017; Golebowicz et al, 2015).

\section{THEME 4: BARRIERS TO TELEREHABILITATION}

This theme identified barriers to the implementation of telerehabilitation, specifically the difficulties of capacity in infrastructure, policies, guidelines, and practitioner expertise. Infrastructure and resourcing issues presented a major barrier. These included ways in which standards and processes for information and communication technologies (ICT) and engaging service providers/users from the initial implementation stages of a telehealth project could directly impact the integration of telerehabilitation services into practice. Consequently, the barriers involved a lack of funding and investments into infrastructure; the high cost of ICT; the rapidly changing nature of ICT; and ICT innovation needs, such as the availability of suitable devices and equipment, internet speed, and usability (Aloyuni et al., 2020; Bonnechère et al., 2017; Ullah et al., 2020).

The lack of telerehabilitation privacy policies, standards, guidelines, and data protection regulations was found to create risks such as compromised patient data security and patient privacy, and consultations with unauthorised persons (Ullah et al., 2020). 
The lack of collaboration between educational and governmental authorities in establishing local telerehabilitation guidelines was another barrier. Such guidelines must be fully compatible with local conditions, such as culture and language, local telerehabilitation scenarios, the rehabilitation strategies of the local teams, and localized functional evaluation of the patients (Bonnechère et al., 2017; Ullah et al., 2020).

Barriers also included challenges related to human capacity-building in the development of knowledge, skills, and attitude for both providers and patients. There was a lack of awareness and knowledge about telerehabilitation technologies and applications among patients and rehabilitation professionals (Alqahtani, 2019; Aloyuni et al., 2020; Ullah et al., 2020).

Telerehabilitation training is required for rehabilitation providers and patients to use the relevant technology, and continuous support will also increase their confidence (Alqahtani, 2019; Azma et al., 2018; Ullah et al., 2020). It was reported that the patients' confidence in using the telerehabilitation platform increased after their first experience (Alqahtani, 2019). There was a lack of expertise regarding telerehabilitation adoption of technology and a shortage of human capital (Aloyuni et al., 2020). A lack of acceptance among clinicians is one likely reason for the low uptake and maintenance of telerehabilitation (Alqahtani, 2019; Ullah et al., 2020). Policymakers' attitudes also obstructed the use of telerehabilitation services (Aloyuni et al., 2020; Ullah et al., 2020).

The cultural and social context was considered a barrier limiting telerehabilitation implementation (Bonnechère et al., 2017; Ullah et al., 2020); for example, patients undertook physical rehabilitation activities fully clothed (Bonnechère et al., 2017). 
International Journal of Telerehabilitation • telerehab.pitt.edu

Table 3

Study Characteristics

\begin{tabular}{|c|c|c|c|c|c|c|c|c|c|c|c|c|c|}
\hline Source & Year & Country & $\begin{array}{l}\text { Research } \\
\text { aim }\end{array}$ & \begin{tabular}{|l|} 
Research \\
design \\
[quality rating]
\end{tabular} & \begin{tabular}{|l|} 
Sample \\
size \\
Age \\
(mean, \\
variance)
\end{tabular} & $\begin{array}{l}\text { Sample } \\
\text { Gender } \\
\text { (male n; } \\
\text { female n) }\end{array}$ & $\begin{array}{l}\text { Sample } \\
\text { primary } \\
\text { Diagnosis/ } \\
\text { Condition }\end{array}$ & $\begin{array}{l}\text { Measures } \\
\text { used in study* }\end{array}$ & $\begin{array}{l}\text { Intervention } \\
\text { (brief } \\
\text { description) }\end{array}$ & $\begin{array}{l}\text { Disciplines } \\
\text { involved in } \\
\text { intervention }\end{array}$ & $\begin{array}{l}\text { Technologies } \\
\text { used in delivery }\end{array}$ & \begin{tabular}{|l} 
Site \\
where \\
rehab \\
received
\end{tabular} & Outcome \\
\hline \multicolumn{14}{|c|}{ PATIENT INTERVENTION STUDIES } \\
\hline $\begin{array}{l}\text { Alasfour \& } \\
\text { Almarwani }\end{array}$ & 2020 & $\begin{array}{l}\text { Saudi } \\
\text { Arabia }\end{array}$ & \begin{tabular}{|l|} 
To \\
determine if \\
the study- \\
specific \\
Arabic smart \\
phone app \\
'My Dear \\
Knee' \\
increases \\
exercise \\
program \\
adherence.
\end{tabular} & $\begin{array}{l}\text { RCT } \\
\text { App group } \\
\text { n=20; control } \\
\text { group } C=20) \\
\text { CASP: Good } \\
\end{array}$ & \begin{tabular}{|l|}
$\mathrm{N}=40$ \\
Mean age \\
$54.4(+/-$ \\
4.33 \\
years $)$
\end{tabular} & $\begin{array}{l}40 \\
\text { females }\end{array}$ & $\begin{array}{l}\text { Osteo- } \\
\text { arthritis in } \\
\text { knee }\end{array}$ & $\begin{array}{l}\text { Self-reported } \\
\text { adherence to } \\
\text { prescribed } \\
\text { home exercise } \\
\text { program; } \\
\text { Arabic numeric } \\
\text { pain rating } \\
\text { scale; Arabic } \\
\text { version of the } \\
\text { reduced } \\
\text { Western } \\
\text { Ontario, } \\
\text { McMaster } \\
\text { Universities } \\
\text { Osteoarthritis } \\
\text { Index Physical } \\
\text { Function } \\
\text { subscale, and } \\
\text { Five-Times Sit- } \\
\text { To-Stand Test } \\
\text { scores. }\end{array}$ & \begin{tabular}{|l|}
6 weeks \\
exercise \\
program with \\
home exercise \\
- paper \\
resource \\
versus smart- \\
phone-app
\end{tabular} & $\begin{array}{l}\text { Physio- } \\
\text { therapist only }\end{array}$ & $\begin{array}{l}\text { Smart phone } \\
\text { Author- } \\
\text { designed app } \\
\text { 'my dear knee' }\end{array}$ & home & $\begin{array}{l}\text { App group } \\
\text { has reduced } \\
\text { pain, } \\
\text { increased } \\
\text { physical } \\
\text { function, } \\
\text { increased } \\
\text { lower limb } \\
\text { strength and } \\
\text { increased } \\
\text { program } \\
\text { adherence } \\
\text { compared to } \\
\text { control }\end{array}$ \\
\hline
\end{tabular}


International Journal of Telerehabilitation • telerehab.pittedu

\begin{tabular}{|c|c|c|c|c|c|c|c|c|c|c|c|c|c|}
\hline Azma et al & 2018 & Iran & $\begin{array}{l}\text { To evaluate } \\
\text { the impact } \\
\text { of } \\
\text { telerehabili- } \\
\text { tation office } \\
\text { based } \\
\text { physiothera } \\
\text { py versus } \\
\text { conventional } \\
\text { therapy on } \\
\text { function and } \\
\text { OA } \\
\text { symptoms. }\end{array}$ & $\begin{array}{l}\text { RCT } \\
\text { CASP: } \\
\text { Moderate }\end{array}$ & \begin{tabular}{|l|}
76 \\
random- \\
ized; \\
$\mathrm{N}=54$ \\
completed \\
\\
58.25 \\
years \\
$(+/-7.41 ;$ \\
range $45-$ \\
60 years $)$
\end{tabular} & \begin{tabular}{|l|}
$\mathrm{n}=21$ \\
males \\
$\mathrm{n}=33$ \\
females \\
Reported \\
as a \% of \\
all partici-' \\
pants but \\
unclear if \\
this refers \\
to all \\
randomis \\
ed or all \\
completed \\
- \\
completed \\
reported \\
here
\end{tabular} & $\begin{array}{l}\text { Knee } \\
\text { osteoarthrit } \\
\text { is }\end{array}$ & $\begin{array}{l}\text { Persian } \\
\text { version of } \\
\text { Knee injury } \\
\text { and } \\
\text { Osteoarthritis } \\
\text { Outcome } \\
\text { Score (KOOS); } \\
\text { Visual } \\
\text { Analogue } \\
\text { Scale (VAS); } \\
\text { Western } \\
\text { Ontario and } \\
\text { McMaster } \\
\text { Universities } \\
\text { Osteoarthritis } \\
\text { Index } \\
\text { (WOMAC) } \\
\text { (pain, ADL, } \\
\text { symptom, } \\
\text { sport, QoL } \\
\text { subscales) }\end{array}$ & \begin{tabular}{|l|}
18 sessions/6 \\
weeks each \\
group. \\
Telerehabilit- \\
ation group \\
received face \\
to face \\
instruction in \\
exercises, \\
information \\
pamphlet, \\
then home \\
practice, with \\
weekly \\
monitoring call \\
by doctor by \\
phone; \\
Control group: \\
passive \\
therapies \\
physiotherapy \\
in clinic \\
services.
\end{tabular} & $\begin{array}{l}\text { Tele- } \\
\text { rehabilitation } \\
\text { group: } \\
\text { physical } \\
\text { therapist } \\
\text { instruction } \\
\text { then physical } \\
\text { rehabilitation } \\
\text { specialist } \\
\text { doctor follow } \\
\text { up; Control } \\
\text { group: } \\
\text { physical } \\
\text { therapist at } \\
\text { clinic. }\end{array}$ & $\begin{array}{l}\text { Phone - } \\
\text { assisted tele- } \\
\text { rehabilitation } \\
\text { call on weekly } \\
\text { basis versus } \\
\text { physical } \\
\text { therapy clinic }\end{array}$ & \begin{tabular}{|l} 
Both \\
groups \\
in clinic \\
instruct- \\
ion, then \\
home \\
tele- \\
rehabilit \\
ation \\
group \\
versus \\
in-clinic \\
physio- \\
therapy
\end{tabular} & $\begin{array}{l}\text { Both groups } \\
\text { improved on } \\
\text { pain and } \\
\text { function; no } \\
\text { significant } \\
\text { difference } \\
\text { between tele- } \\
\text { rehabilitation } \\
\text { and in-clinic } \\
\text { service - } \\
\text { tele- } \\
\text { rehabilitation } \\
\text { equivalent } \\
\text { outcomes to } \\
\text { traditional } \\
\text { clinic service }\end{array}$ \\
\hline $\begin{array}{l}\text { Golebowicz } \\
\text { et al. }\end{array}$ & 2015 & Israel & $\begin{array}{l}\text { To } \\
\text { determine if } \\
\text { an } \\
\text { ergonomic } \\
\text { intervention } \\
\text { followed by } \\
\text { electronic } \\
\text { biofeedback } \\
\text { self-practice } \\
\text { for 4-6 } \\
\text { weeks at } \\
\text { work } \\
\text { reduced } \\
\text { upper limb } \\
\text { musculo- } \\
\text { skeletal } \\
\text { symptoms }\end{array}$ & $\begin{array}{l}\text { Observational } \\
\text { prospective } \\
\text { cohort study } \\
\text { CASP: } \\
\text { Moderate }\end{array}$ & \begin{tabular}{|l|}
$\mathrm{N}=12$ \\
34.25 \\
years (24- \\
$58)$
\end{tabular} & $\begin{array}{l}6 \text { males; } \\
6 \text { females }\end{array}$ & $\begin{array}{l}\text { Computer } \\
\text { operators } \\
\text { with work - } \\
\text { related } \\
\text { musculo- } \\
\text { skeletal } \\
\text { disorders }\end{array}$ & $\begin{array}{l}\text { Bio- } \\
\text { demographic } \\
\text { questionnaire; } \\
\text { Pre-post } \\
\text { PROM } \\
\text { Standard } \\
\text { Nordic } \\
\text { Questionnaire; } \\
\text { pre-post } \\
\text { PROM } \\
\text { Swedish } \\
\text { Demand } \\
\text { Control } \\
\text { Support } \\
\text { Questionnaire; } \\
\text { pre-post Rapid } \\
\text { Upper Limb } \\
\text { Assessment; }\end{array}$ & \begin{tabular}{|l|} 
Workplace \\
assessment \\
and \\
adjustment; \\
provision of \\
biofeedback \\
and \\
installation of \\
program on \\
each person's \\
workstation; \\
for self- \\
practice use \\
4-6 weeks
\end{tabular} & $\begin{array}{l}\text { Occupational } \\
\text { therapist only }\end{array}$ & $\begin{array}{l}\text { Exercise data } \\
\text { via a tele- } \\
\text { rehabilitation } \\
\text { biofeedback } \\
\text { system }\end{array}$ & $\begin{array}{l}\text { Work- } \\
\text { place }\end{array}$ & \begin{tabular}{|l|} 
Upper \\
extremity \\
symptoms \\
reduced, \\
regions of \\
pain and \\
activity \\
limitations \\
from pain \\
reduced, \\
body posture \\
improved
\end{tabular} \\
\hline
\end{tabular}


International Journal of Telerehabilitation $\bullet$ telerehab.pittedu

\begin{tabular}{|c|c|c|c|c|c|c|c|c|c|c|c|c|c|}
\hline & & & $\begin{array}{l}\text { including } \\
\text { pain. }\end{array}$ & & & & & $\begin{array}{l}\text { surface } \\
\text { electromyogra } \\
\text { phy; pre-post } \\
\text { physical } \\
\text { examination } \\
\text { for upper } \\
\text { extremity } \\
\text { symptoms. }\end{array}$ & & & & & \\
\hline Kalron et al. & 2018 & Israel & $\begin{array}{l}\text { To evaluate } \\
\text { effects of } \\
\text { telerehab- } \\
\text { ilitation on } \\
\text { mobility in } \\
\text { people } \\
\text { following hip } \\
\text { surgery. }\end{array}$ & $\begin{array}{l}\text { RCT } \\
\text { CASP Good }\end{array}$ & \begin{tabular}{|l|}
$\mathrm{N}=40$ \\
random- \\
ized; 32 \\
completed \\
\\
mean age \\
controls \\
67.3 (SD \\
$9.5)$; tele- \\
rehab- \\
ilitation of \\
$65.7 .(7.8)$
\end{tabular} & $\begin{array}{l}\text { Gender } \\
\text { data } \\
\text { provided } \\
\text { for: } 17 \\
\text { males; } 19 \\
\text { females }\end{array}$ & hip surgery & $\begin{array}{l}\text { The Timed Up } \\
\text { and Go test, 2- } \\
\text { min walk test, } \\
10-m \text { walk test, } \\
\text { sit to stand } \\
\text { test, walking } \\
\text { speed, and } \\
\text { mean step } \\
\text { length. }\end{array}$ & \begin{tabular}{|l|}
6 weeks, 3 \\
sessions/week \\
tele- \\
rehabilitation \\
versus control \\
intervention \\
group
\end{tabular} & $\begin{array}{l}\text { Physio- } \\
\text { therapist }\end{array}$ & $\begin{array}{l}\text { video-based } \\
\text { tele- } \\
\text { rehabilitation } \\
\text { program. }\end{array}$ & home & \begin{tabular}{|l} 
Tele- \\
rehabilitation \\
$(\mathrm{n}=15)$ \\
significantly \\
higher in all \\
mobility \\
outcomes \\
than control \\
$(n=17)$
\end{tabular} \\
\hline Kargar et al. & 2020 & Iran & \begin{tabular}{|l|} 
To evaluate \\
the impact \\
of tele- \\
rehabilit- \\
ation (hand- \\
burn self- \\
care \\
educational \\
application) \\
versus \\
conventional \\
therapy.
\end{tabular} & $\begin{array}{l}\text { RCT } \\
\text { CASP: } \\
\text { Moderate }\end{array}$ & \begin{tabular}{|l|}
$\mathrm{N}=60$ \\
30 in each \\
group; \\
Tele- \\
rehabilit- \\
ation 38.2 \\
years $(+/-$ \\
$11.7)$ \\
Control \\
43.6 years \\
$(+/-12.6)$
\end{tabular} & $\begin{array}{l}44 \text { males; } \\
16 \\
\text { females }\end{array}$ & Burns & \begin{tabular}{|l|} 
Type of burn; \\
The Burn- \\
Specific Health \\
Scale-Brief \\
(BSHS-B) \\
(includes QoL \\
scales)
\end{tabular} & $\begin{array}{l}\text { Both groups } \\
\text { receive self- } \\
\text { care training } \\
\text { during } \\
\text { admission and } \\
\text { at discharge } \\
\text { provided in- } \\
\text { person by } \\
\text { nurse with } \\
\text { information } \\
\text { pamphlet; } \\
\text { Tele- } \\
\text { rehabilitation } \\
\text { group also } \\
\text { received } \\
\text { instruction on } \\
\text { the hand self- } \\
\text { care app } \\
\text { which } \\
\text { included: } \\
\text { educational } \\
\text { materials, }\end{array}$ & \begin{tabular}{|l|} 
Control group: \\
nurses. \\
App group \\
nurses plus \\
app clinicians \\
plus medical \\
professionals \\
and 'health \\
care \\
providers' \\
(e.g., \\
surgeons, \\
nurses, \\
physio- \\
therapists, \\
and nutrition \\
consultants).
\end{tabular} & $\begin{array}{l}\text { Author } \\
\text { developed } \\
\text { burns self-care } \\
\text { app }\end{array}$ & Home & $\begin{array}{l}\text { Within group } \\
\text {,QoL } \\
\text {,physical } \\
\text { psychological } \\
\text { and social } \\
\text { dimensions } \\
\text { and aspects } \\
\text { of QoL } \\
\text { improved for } \\
\text {;both groups } \\
\text {,QoL } \\
\text {,physical } \\
\text { pyshological } \\
\text { and social } \\
\text { dimensions } \\
\text { and aspects } \\
\text { of QoL } \\
\text { significanty } \\
\text { higher for } \\
\text { app group }\end{array}$ \\
\hline
\end{tabular}




\begin{tabular}{|c|c|c|c|c|c|c|c|c|c|c|c|c|c|}
\hline & & & & & & & & & $\begin{array}{l}\text { opportunity to } \\
\text { send pictures } \\
\text { via chat and } \\
\text { messaging } \\
\text { system; Q\&A } \\
\text { answering; } \\
\text { referral to } \\
\text { clinic if } \\
\text { needed) }\end{array}$ & & & & \\
\hline $\begin{array}{l}\text { Nabutovsky, } \\
\text { Ashri et al. }\end{array}$ & 2020 & Israel & \begin{tabular}{|l|} 
To evaluate \\
the feasibility, \\
safety, and \\
effective- \\
ness of a \\
cardiac \\
rehabilitation \\
exercise \\
program
\end{tabular} & $\begin{array}{l}\text { Prospective } \\
\text { observational } \\
\text { cohort study } \\
\text { CASP: Good }\end{array}$ & $\begin{array}{l} \\
\text { Mean } \\
\text { age: } \\
52.7,+/- \\
0.81\end{array}$ & $\begin{array}{l}17 \text { males; } \\
5 \text { females }\end{array}$ & $\begin{array}{l}\text { Coronary } \\
\text { artery } \\
\text { disease }\end{array}$ & $\begin{array}{l}\text { Smart-watch } \\
\text { recorded } \\
\text { minutes of } \\
\text { aerobic } \\
\text { exercise }>70 \% \\
\text { VO2Max per } \\
\text { week, no. } \\
\text { resistance } \\
\text { training } \\
\text { sessions per } \\
\text { week, patient } \\
\text { questionnaires, } \\
\text { safety = no. }\end{array}$ & \begin{tabular}{|l|} 
Six-month \\
secondary \\
prevention \\
cardiac \\
exercise \\
program using \\
mobile phone \\
applications \\
and \\
multidisciplina \\
ry cardiac
\end{tabular} & $\begin{array}{l}\text { Telerehabilitat } \\
\text { ion cardiac } \\
\text { specialist, } \\
\text { dietitian, } \\
\text { psychologist, } \\
\text { exercise } \\
\text { physiologist, } \\
\text { physical } \\
\text { education } \\
\text { specialist, } \\
\text { nurse, } \\
\text { kinesiologist }\end{array}$ & \begin{tabular}{|l|} 
Datos Health \\
mobile phone \\
app with \\
multidisciplinary \\
caregiver \\
control center/ \\
dashboard \\
(technical \\
details \\
described in \\
paper)
\end{tabular} & Home & \begin{tabular}{|l|} 
Patient \\
satisfaction \\
and app use \\
high. \\
Significant \\
improve- \\
ment in \\
exercise \\
capacity, \\
functional \\
improve- \\
ment, and \\
consistent \\
\end{tabular} \\
\hline
\end{tabular}


International Journal of Telerehabilitation • telerehab.pitt.edu

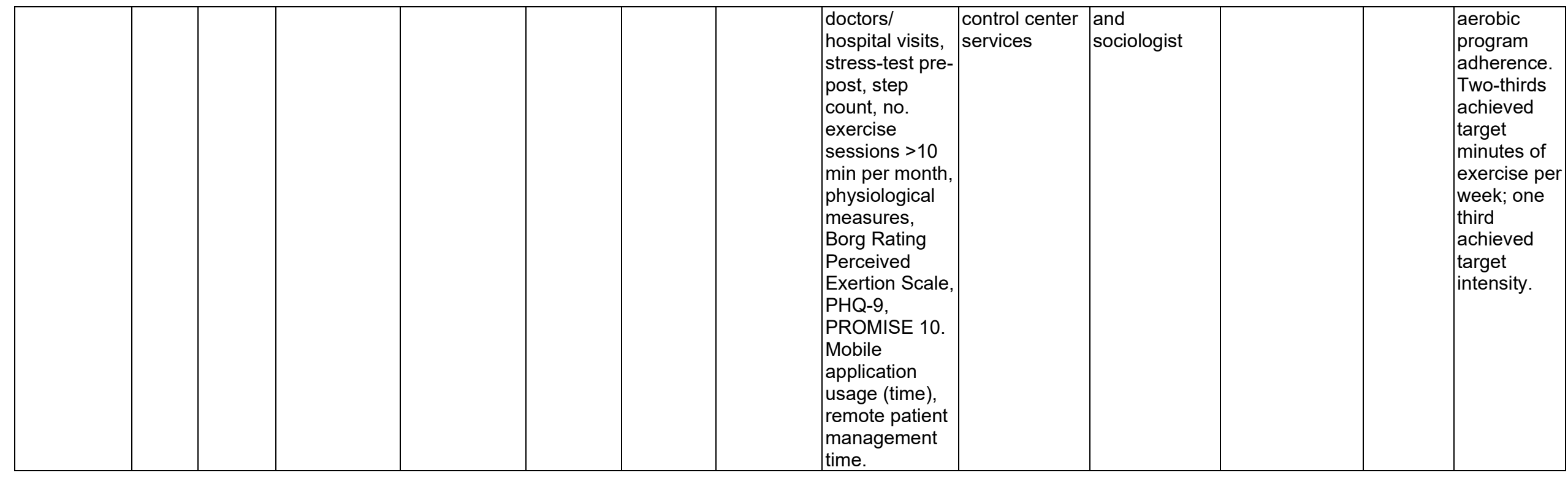


International Journal of Telerehabilitation • telerehab.pittedu

\begin{tabular}{|c|c|c|c|c|c|c|c|c|c|c|c|c|c|}
\hline \multicolumn{14}{|c|}{ PATIENT PERCEPTION STUDIES } \\
\hline Source & Year & Country & $\begin{array}{l}\text { Research } \\
\text { aim }\end{array}$ & $\begin{array}{l}\begin{array}{l}\text { Research } \\
\text { design }\end{array} \\
\text { [quality } \\
\text { rating] }\end{array}$ & \begin{tabular}{|l} 
Sample \\
size \\
Age \\
(mean, \\
variance)
\end{tabular} & $\begin{array}{l}\text { Sample } \\
\text { Gender } \\
\text { (male n; } \\
\text { female } \\
n \text { ) }\end{array}$ & \begin{tabular}{|l} 
Sample \\
primary \\
Diagnosis/ \\
Condition
\end{tabular} & $\begin{array}{l}\text { Measures } \\
\text { used in study* }\end{array}$ & $\begin{array}{l}\text { Intervention } \\
\text { (brief } \\
\text { description) }\end{array}$ & $\begin{array}{l}\text { Disciplines } \\
\text { involved in } \\
\text { intervention }\end{array}$ & $\begin{array}{l}\text { Technologies } \\
\text { used in } \\
\text { delivery }\end{array}$ & $\begin{array}{l}\text { Site where } \\
\text { rehab } \\
\text { received }\end{array}$ & Outcome \\
\hline Alqahtani & 2019 & $\begin{array}{l}\text { Saudi } \\
\text { Arabia }\end{array}$ & \begin{tabular}{|l} 
To evaluate \\
the \\
knowledge, \\
awareness, \\
and \\
perceptions \\
of home \\
health care \\
patients \\
regarding \\
physio- \\
therapy \\
provided \\
through tele- \\
rehabilitation
\end{tabular} & $\begin{array}{l}\text { Prospective } \\
\text { observational } \\
\text { cohort study } \\
\text { CASP: Good }\end{array}$ & $\begin{array}{l}\mathrm{N}=90 \\
(\mathrm{males} \\
65.8,+/- \\
9.4 ; \\
\text { females } \\
58.7,+/- \\
7.8)\end{array}$ & $\begin{array}{l}57 \\
\text { males; } \\
33 \\
\text { females }\end{array}$ & \begin{tabular}{|l|} 
Primary \\
diagnosis \\
of \\
orthopedic \\
problems \\
requiring \\
physical \\
therapy \\
with \\
participant \\
medical \\
condition \\
reported as \\
orthopedic \\
$n=36 ;$ \\
neurology \\
$n=24 ;$ \\
sports \\
$n=15 ;$ other \\
$n=15$
\end{tabular} & $\begin{array}{l}\text { Telehealth } \\
\text { Usability } \\
\text { Questionnaire } \\
\text { (TUQ) - } \\
\text { translated to } \\
\text { Arabic } \\
\text { (awareness, } \\
\text { knowledge, } \\
\text { comfort); } \\
\text { qualitative } \\
\text { interview (on } \\
\text { experience); } \\
\text { interviews } \\
\end{array}$ & \begin{tabular}{|l} 
Proprietary \\
Telerehabilitat \\
ion \\
Technological \\
Solutions \\
service \\
Telemedicine \\
service \\
consists of a \\
portal to track \\
health metrics \\
and \\
rehabilitation \\
treatment plan \\
and progress \\
by the \\
physical \\
therapist, \\
medical \\
specialists as \\
well as the \\
Case \\
Managers
\end{tabular} & $\begin{array}{l}\text { Physical } \\
\text { therapy } \\
\text { professionals, } \\
\text { case manager }\end{array}$ & $\begin{array}{l}\text { The internet } \\
\text { and video } \\
\text { conferencing } \\
\text { equipment } \\
\text { installed at } \\
\text { home and } \\
\text { receiving } \\
\text { services via } \\
\text { video } \\
\text { conference, } \\
\text { including } \\
\text { dealing with } \\
\text { technical } \\
\text { issues. }\end{array}$ & Home & $\begin{array}{l}\text { All } \\
\text { dimensions } \\
\text { of the TUQ } \\
\text { statistically } \\
\text { improved } \\
\text { after } \\
\text { experience } \\
\text { of tele- } \\
\text { rehabilitation } \\
\text { Awareness, } \\
\text { knowledge, } \\
\text { satisfaction } \\
\text { increased } \\
\text { after tele- } \\
\text { rehabilitation } \\
\text { experience }\end{array}$ \\
\hline $\begin{array}{l}\text { Bonnechère } \\
\text { et al. }\end{array}$ & 2017 & Morocco & $\begin{array}{l}\text { To evaluate } \\
\text { the } \\
\text { feasibility } \\
\text { and } \\
\text { acceptability } \\
\text { of video } \\
\text { games in } \\
\text { ambulatory }\end{array}$ & $\begin{array}{l}\text { Prospective } \\
\text { observational } \\
\text { cohort study } \\
\text { CASP: } \\
\text { Moderate }\end{array}$ & $\begin{array}{l}\text { (mean } \\
\text { reported } \\
45 \text { years; } \\
\text { no }\end{array}$ & $\begin{array}{l}7 \text { males; } \\
14 \\
\text { females }\end{array}$ & \begin{tabular}{|l|} 
Tendinitis \\
wrist/hand; \\
Low back \\
pain; \\
ankylosing \\
spondylitis, \\
patella \\
instability;
\end{tabular} & $\begin{array}{l}\text { Author-design } \\
\text { questionnaire } \\
\text { about video } \\
\text { game } \\
\text { exposure and } \\
\text { access to } \\
\text { Information } \\
\text { technology; list }\end{array}$ & $\begin{array}{l}\text { Physical } \\
\text { therapy in } \\
\text { ambulatory } \\
\text { care with } \\
\text { inclusion of } \\
\text { video game } \\
\text { instruction }\end{array}$ & $\begin{array}{l}\text { Physical } \\
\text { therapist }\end{array}$ & $\begin{array}{l}\text { Mini games } \\
\text { developed by } \\
\text { authors for } \\
\text { physical } \\
\text { rehabilitation, } \\
\text { exercise } \\
\text { reminder }\end{array}$ & $\begin{array}{l}\text { Ambulatory } \\
\text { physical } \\
\text { therapy } \\
\text { service } \\
\text { department }\end{array}$ & $\begin{array}{l}\text { Games were } \\
\text { feasible in } \\
\text { clinic } \\
\text { setting, } \\
\text { patients } \\
\text { willing to try } \\
\text { them at } \\
\text { home, } 19 \%\end{array}$ \\
\hline
\end{tabular}


International Journal of Telerehabilitation • telerehab.pittedu

\begin{tabular}{|c|c|c|c|c|c|c|c|c|c|c|c|c|c|}
\hline & & & $\begin{array}{l}\text { physical } \\
\text { therapy. }\end{array}$ & & $\begin{array}{l}\text { variance } \\
\text { reported) }\end{array}$ & & $\begin{array}{l}\text { foot } \\
\text { fractures; } \\
\text { balance } \\
\text { problems; } \\
\text { gait } \\
\text { training; } \\
\text { hemi- } \\
\text { paresis }\end{array}$ & $\begin{array}{l}\text { of games } \\
\text { used; extent of } \\
\text { home use } \\
\text { (habit); author } \\
\text { designed } \\
\text { survey on } \\
\text { game } \\
\text { acceptability; } \\
\text { Bonnechère } \\
\text { survey on } \\
\text { home exercise } \\
\text { translated to } \\
\text { Arabic. }\end{array}$ & $\begin{array}{l}\text { and use at } \\
\text { home }\end{array}$ & & $\begin{array}{l}\text { using smart } \\
\text { phone/ email }\end{array}$ & & $\begin{array}{l}\text { afraid of } \\
\text { falling during } \\
\text { game, may } \\
\text { help habit } \\
\text { formation } \\
\text { (only } \\
\text { descriptive } \\
\text { data } \\
\text { presented) }\end{array}$ \\
\hline $\begin{array}{l}\text { Nabutovsky, } \\
\text { Nachshon et } \\
\text { al. }\end{array}$ & 2020 & Israel & \begin{tabular}{|l|} 
Attitudes, \\
perceptions, \\
and \\
behavioral \\
intentions \\
toward \\
remote \\
digital \\
cardiac \\
rehabilitation \\
\end{tabular} & $\begin{array}{l}\text { Cross } \\
\text { sectional } \\
\text { survey } \\
\text { JBI: Good }\end{array}$ & $\begin{array}{l}\mathrm{N}=197 \\
\text { Mean age } \\
64.8 \\
\text { years } \\
+/-11.13 \\
(20 \text { to } 91 \\
\text { years })\end{array}$ & $\begin{array}{l}\text { males; } \\
139 ; 61 \\
\text { females }\end{array}$ & \begin{tabular}{|l|} 
cardiac \\
conditions
\end{tabular} & $\begin{array}{l}33 \text { questions } \\
\text { included } \\
\text { Demographic } \\
\text { characteristics; } \\
\text { Lifestyle; } \\
\text { Technological } \\
\text { literacy and } \\
\text { patterns of use } \\
\text { of mobile } \\
\text { phones, } \\
\text { internet, } \\
\text { computer, and } \\
\text { monitoring } \\
\text { devices.; } \\
\text { Interest to } \\
\text { receive health } \\
\text { content } \\
\text { through mobile } \\
\text { phone; Interest } \\
\text { to participate in } \\
\text { a digital heart } \\
\text { rehabilitation } \\
\text { program and } \\
\text { get telephone } \\
\text { support }\end{array}$ & $\begin{array}{l}\text { Recuperation } \\
\text { hotel } \\
\text { accommodati } \\
\text {;on } \\
\text { rehabilitation } \\
\text { clinic - no } \\
\text { telerehabilitati } \\
\text { on } \\
\text { - intervention } \\
\text { this was } \\
\text { exploring } \\
\text { attritues } \\
\text { towards } \\
\text { potential use }\end{array}$ & $\begin{array}{l}\text { No particular } \\
\text { rehabilitation } \\
\text { professionals } \\
\text { identified - } \\
\text { participant } \\
\text { perspectives } \\
\text { were about } \\
\text { the use of } \\
\text { tele- } \\
\text { rehabilitation } \\
\text { approach in } \\
\text { general. }\end{array}$ & \begin{tabular}{|l|} 
A range of \\
approaches \\
were \\
identified and \\
perspectives \\
sought: \\
cardiac-rehab \\
tele- \\
counselling; \\
remote digital \\
cardiac rehab; \\
cardiac rehab \\
support via \\
internet; \\
exercise \\
program by \\
computer \\
game; control \\
over game \\
configurations \\
; virtual rehab \\
class; \\
physical \\
activity \\
monitoring
\end{tabular} & $\begin{array}{l}\text { Rehab- } \\
\text { ilitation } \\
\text { center }\end{array}$ & $\begin{array}{l}\text { Mobile } \\
\text { phone: Text } \\
\text { messaging } \\
\text { was the } \\
\text { most } \\
\text { desired as } \\
\text { well as e- } \\
\text { mail and } \\
\text { video clips; } \\
\text { internet; } \\
\text { virtual reality } \\
\text { for lifestyle } \\
\text { managemen } \\
\text { t, nutrition, } \\
\text { physical } \\
\text { activity, and } \\
\text { mental well- } \\
\text { being. }\end{array}$ \\
\hline
\end{tabular}


International Journal of Telerehabilitation • telerehab.pittedu

\begin{tabular}{|c|c|c|c|c|c|c|c|c|c|c|c|c|c|}
\hline \multicolumn{14}{|c|}{ HEALTH PROFESSIONAL PERCEPTION STUDIES } \\
\hline Source & Year & Country & Research aim & $\begin{array}{l}\text { Research } \\
\text { design } \\
\text { [quality } \\
\text { rating] }\end{array}$ & \begin{tabular}{|l} 
Sample \\
size \\
Age \\
(mean, \\
variance)
\end{tabular} & $\begin{array}{l}\text { Sample } \\
\text { Gender } \\
\text { (male n; } \\
\text { female } \\
n \text { ) }\end{array}$ & $\begin{array}{l}\text { Sample } \\
\text { primary } \\
\text { Diagnosis/ } \\
\text { Condition }\end{array}$ & $\begin{array}{l}\text { Measures } \\
\text { used in study* }\end{array}$ & $\begin{array}{l}\text { Intervention } \\
\text { (brief } \\
\text { description) }\end{array}$ & $\begin{array}{l}\text { Disciplines } \\
\text { involved in } \\
\text { intervention }\end{array}$ & $\begin{array}{l}\text { Technologie } \\
\text { s used in } \\
\text { delivery }\end{array}$ & $\begin{array}{l}\text { Site where } \\
\text { rehab } \\
\text { received }\end{array}$ & Outcome \\
\hline $\begin{array}{l}\text { Aloyuni et } \\
\text { al. }\end{array}$ & 2020 & $\begin{array}{l}\text { Saudi } \\
\text { Arabia }\end{array}$ & $\begin{array}{l}\text { Nationwide } \\
\text { survey of } \\
\text { knowledge, } \\
\text { attitudes } \\
\text { towards, and } \\
\text { perceived } \\
\text { barriers to } \\
\text { implementing } \\
\text { telerehab- } \\
\text { ilitation in } \\
\text { physical } \\
\text { therapy } \\
\text { practice; } \\
\text { including } \\
\text { survey } \\
\text { instrument } \\
\text { development } \\
\text { of these } \\
\text { factors }\end{array}$ & $\begin{array}{l}\text { Cross } \\
\text { sectional } \\
\text { survey } \\
\text { JBI: } \\
\text { Moderate }\end{array}$ & $\begin{array}{l}\mathrm{N}=347 \\
\text { Age not } \\
\text { reported }\end{array}$ & $\begin{array}{l}106 \\
\text { males; } \\
70 \\
\text { females }\end{array}$ & N/A & $\begin{array}{l}\text { Author- } \\
\text { developed } 14 \\
\text { item survey - } \\
\text { demographic } \\
\text { information, } \\
\text { telerehab- } \\
\text { ilitation } \\
\text { knowledge, } \\
\text { attitudes and } \\
\text { barriers to } \\
\text { telerehab- } \\
\text { ilitation }\end{array}$ & $\begin{array}{l}\text { No } \\
\text { - intervention } \\
\text { this was a } \\
\text { survey of } \\
\text { practitioner } \\
\text { perspectives } \\
\text { PTs reported } \\
\text { utilizing tele- } \\
\text { rehabilitation } \\
\text { in assessment } \\
(17 \%), \\
\text { Diagnosis } \\
(3 \%), \\
\text { Prognosis } \\
(4 \%), \\
\text { intervention } \\
(6 \%), \text { and } \\
\text { follow-up } \\
20 \%)\end{array}$ & \begin{tabular}{|l|} 
Physio- \\
therapists only
\end{tabular} & $\begin{array}{l}\text { While } 79 \% \\
\text { used no tele- } \\
\text { rehabilitation } \\
\text { a minority } \\
\text { used mage- } \\
\text { based } \\
\text { telerehab- } \\
\text { ilitation } \\
(10 \%) \text { eg. } \\
\text { Video- } \\
\text { conferencing } \\
\text {; sensor- } \\
\text { based } \\
\text { telerehab- } \\
\text { ilitation (8\%) } \\
\text { eg tilt } \\
\text { swtiches, } \\
\text { acceleromet } \\
\text { ers; virtual } \\
\text { reality } \\
\text { telerehab- } \\
\text { ilitation (3\%). }\end{array}$ & $\begin{array}{l}\text { Hospitals } \\
\text { and rehab- } \\
\text { ilitation } \\
\text { centers } \\
\text { across } 13 \\
\text { provinces } \\
\text { in Saudi } \\
\text { Arabia }\end{array}$ & $\begin{array}{l}\text { have \%58.8 } \\
\text { knowledge } \\
\text { about } \\
\text { telerehab- } \\
\text { ilitation; } \\
31.7 \% \\
\text { reported } \\
\text { their } \\
\text { workplaces } \\
\text { had } \\
\text { equipment } \\
\text { needed; } \\
\text { main } \\
\text { barriers; } \\
\text { staff skills, } \\
\text { technical } \\
\text { issues and } \\
\text { cost }\end{array}$ \\
\hline Ullah et al. & 2020 & $\begin{array}{l}\text { Saudi } \\
\text { Arabia }\end{array}$ & $\begin{array}{l}\text { Nationwide } \\
\text { survey of } \\
\text { Knowledge, } \\
\text { attitudes } \\
\text { towards } \\
\text { implementing } \\
\text { telerehab- } \\
\text { ilitation and } \\
\text { current } \\
\text { practice }\end{array}$ & \begin{tabular}{|l|} 
Cross section \\
survey \\
JBI: \\
Moderate
\end{tabular} & $\begin{array}{l}\mathrm{N}=82 \\
\text { Age not } \\
\text { reported }\end{array}$ & \begin{tabular}{|l}
52 \\
males; \\
30 \\
females
\end{tabular} & $\mathrm{N} / \mathrm{A}$ & $\begin{array}{l}14 \text { close- } \\
\text { ended } \\
\text { questions } \\
\text { targeting five } \\
\text { domains: } \\
\text { demographics, } \\
\text { telemedicine } \\
\text { knowledge, } \\
\text { telerehab- } \\
\text { ilitation service } \\
\text { knowledge, }\end{array}$ & \begin{tabular}{|l} 
No \\
- intervention \\
this was a \\
survey of \\
practitioner \\
perspectives
\end{tabular} & \begin{tabular}{|l|} 
Physical \\
medicine and \\
rehabilitation \\
(PM\&R) \\
physicians, \\
orthotist// \\
prosthetist, \\
physio- \\
therapists, \\
psychologists, \\
occupational
\end{tabular} & $\begin{array}{l}\text { Access to } \\
\text { the following: } \\
\text { smart phone/ } \\
\text { simple } \\
\text { phone }\end{array}$ & $\begin{array}{l}\text { Primary, } \\
\text { secondary, } \\
\text { tertiary } \\
\text { hospitals }\end{array}$ & $\begin{array}{l}\text { Most } \\
\text { participants } \\
\text { think } \\
\text { telerehab- } \\
\text { ilitation is } \\
\text { important, } \\
\text { but most are } \\
\text { not currently } \\
\text { involved. } \\
\text { There is a } \\
\text { need for }\end{array}$ \\
\hline
\end{tabular}


International Journal of Telerehabilitation • telerehab.pittedu

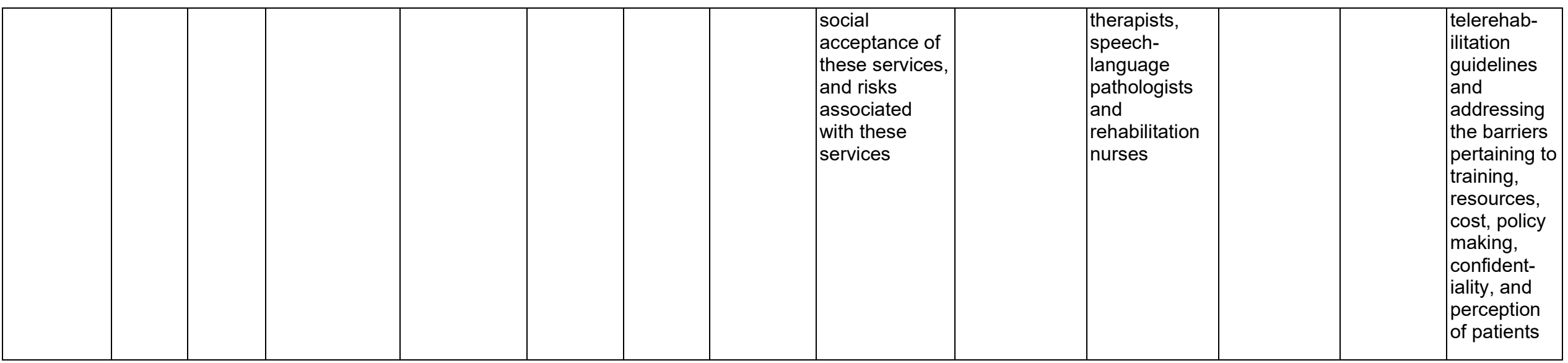




\section{DISCUSSION}

This structured review aimed to characterize and summarize information published in peer-reviewed journals about telerehabilitation practice in MENA. All included sources were recent (i.e., in the past five years). This aligns with previous $\mathrm{WHO}$ reports indicating telehealth practice was increasing in this region. The upward trajectory of publication numbers indicates more research evidence will emerge in years to come. Currently, telerehabilitation studies were limited to only a quarter of all MENA countries; 15 MENA countries had no sources identified. It is hoped that evidence will emerge from as yet unrepresented MENA countries, so in time a more complete picture of telerehabilitation in this region can be made. No systematic review could be located and the present study did not have the data necessary for a meta-analysis. However, this study provides the only current summary and synthesis of research evidence on telerehabilitation in this region or from/about any country within the MENA region.

Research studies used RCT, cohort, and cross-sectional study designs, a variety of outcome measures and were of moderate to good methodological quality. Studies were either evaluations of telerehabilitation interventions ( $n=7)$ conducted in homes or in the workplace using a variety of technologies and platforms, or they were studies about practitioner or patient perceptions of current/future telerehabilitation $(n=5)$. Interventions all produced positive significant outcomes. In intervention studies, health conditions of patient participants were cardiovascular, musculoskeletal, neurological or burns. Only one of these conditions, cardiovascular, is a major cause of MENA mortality; non-communicable disease (NCD) accounts for 74\% of all deaths in MENA (Kaneda \& El-Saharty, 2017) and the four most common MENA NCDs are cardiovascular, diabetes, cancer, and chronic respiratory disease. Each of these NCDs produce impairment, activity limitation and participation restrictions that could benefit from rehabilitation interventions. Future research could explore use of telerehabilitation in management of the consequences of these other common NCDs.

Rehabilitation intervention professionals involved were occupational therapists, physical therapists, rehabilitation doctors or, in two papers, "multidisciplinary rehabilitation teams" with broad engagement. Involvement of these disciplines in telerehabilitation is consistent with international professional practice standards (e.g., World Federation of Occupational Therapists, 2021; World Physiotherapy, 2019). Studies exploring professionals' perceptions about the current or future use of telerehabilitation included disciplines beyond the three named disciplines in intervention studies; but most evidence about professionals' perceptions came from physical therapists in Saudi Arabia. Future research should explore perceptions of health professionals from different disciplines, from those who work in teams versus those who work without collaboration, and from different countries in MENA. Such information could help build an understanding of the appetite and readiness for telerehabilitation practice in addition to capacity and development needs.

Narrative synthesis of content revealed four themes. The first was "rehabilitation availability and accessibility." The challenges of insufficient provision of rehabilitation services, concentration of services in major metropolitan settings and lack of community-based rehabilitation aligned with WHO reports of rehabilitation service challenges in the MENA region (WHO, 2011, 2019, 2020).

The second theme was "perceptions of telerehabilitation." Here, patients perceived telerehabilitation to be user-friendly and an acceptable approach for intervention or follow up with good patient satisfaction. This reflects similar positive patient views about usability, acceptability, and satisfaction revealed in a recent global systematic review of stakeholder adoption of telerehabilitation services (Niknejad Ismail, Bahari \& Nazari, 2021). Professionals were also positive in their perceptions about the value of telerehabilitation even though most had not used it. This finding suggests more research is needed regarding rehabilitation professionals' acceptance of and readiness to use technology for rehabilitation service delivery in practice - a conclusion also drawn by Niknejad et al (2021).

The third theme was "telerehabilitation to augment traditional rehabilitation services." In this theme, the weight of evidence tended toward telerehabilitation as complementing rather than replacing traditional in-person rehabilitation services (e.g., as follow-up or as an additional service) (Laver et al., 2020). This was also reported in the systematic review by Niknejad et al (2021). That study also found concerns by health professionals about the increased work responsibilities that come from use of technology-enabled telerehabilitation and perceived risks to professional status. Further research about these and other issues relating to telerehabilitation in MENA as an augmentative or alternative to in-person service is worth investigation.

The fourth and final theme, "barriers to telerehabilitation" covered resource, training and capacity issues. Some of these have previously been identified in literature, as examples: insufficient hardware and software, low connectivity and reliance on decisions made by management (Jafni, Bahari, Ismail \& Hanafi, 2019). Barriers to telerehabilitation revealed in this review were: 
- Systematic barriers relating to rehabilitation workforce shortages in general (Bonnechère et al., 2017; Ullah et al., 2020), and reliance on rehabilitation administrators' decisions regarding practice delivery and resources (Aloyuni et al., 2020; Ullah et al., 2020).

- Information technology infrastructure limitations in the health system and the economy in general (Aloyuni et al., 2020; Bonnechère et al., 2017; Golebowicz et al., 2015; Ullah et al., 2020) and a reliance on mobile phones (Alasfour \& Almarwani, 2020; Azma et al., 2018; Kargar et al., 2020; Nabutovsky, Ashri et al., 2020; Nabutovsky, Nachschon et al., 2020).

- Lack of awareness, acceptance, confidence, expertise and implementation-ready staff and patients (Alqahtani, 2019; Azma et al., 2018; Aloyuni et al., 2020; Ullah et al., 2020), and

- $\quad$ Lack of guidelines and policy arrangements to support confidentiality and security of technology-enabled rehabilitation in ways that not only protect patients and staff but are also appropriate to cultural and religious norms and standards specifically related to MENA (Bonnechère et al., 2017; Ullah et al., 2020).

Despite these barriers, the review also identified a number of enablers of uptake:

- Widespread availability and use of smart-phone features and the acceptability and utility of the phone as a platform for rehabilitation interventions (Alasfour \& Almarwani, 2020; Azma et al., 2018; Kargar et al., 2020; Nabutovsky, Ashri et al., 2020; Nabutovsky, Nachschon et al., 2020).

- Positive attitudes of rehabilitation professionals and patients to the idea of telerehabilitation and willingness to participate (Alqahtani, 2019; Bonnechère et al., 2017; Nabutovsky, Nachschon et al., 2020a; Ullah et al., 2020).

- Successful examples of telerehabilitation implementation with a range of diagnostic groups, with different rehabilitation personnel as providers from distance (Alasfour \& Almarwani, 2020; Azma et al., 2018; Golebowicz et al., 2015; Kalron et al., 2018; Kargar et al., 2020; Kizony et al., 2017; Nabutovsky, Ashri et al., 2020).

- Increased program adherence and participation observed with telerehabilitation (Alasfour \& Almarwani, 2020; Kalron et al., 2018; Nabutovsky, Ashri et al., 2020a).

- $\quad$ Ease of participation for patients particularly in relation to reduced work absence and saving time (Alasfour \& Almarwani, 2020; Azma et al., 2018; Golebowicz et al., 2015; Nabutovsky, Ashri et al., 2020).

- Use of telerehabilitation technologies in treatment training increased patients' confidence and comfortability (Alqahtani, 2019; Bonnechère et al., 2017), and

- Noticeable health outcomes for patients in telerehabilitation programs (Alasfour \& Almarwani, 2020; Kalron et al., 2018; Kargar et al., 2020).

\section{LIMITATIONS}

This review used a structured, replicable approach across multiple databases to summarize and appraise sources relevant to telerehabilitation in the MENA region. There were limitations in the design of the study. The search ended March 2021. Only peer-reviewed published sources in English were included, even though one of the investigators was fluent in Arabic. While this limited the number of research studies included in the analysis, other sources in Arabic or that did not meet inclusion criteria but were relevant to the topic, were included in the introduction section of this paper, for example, Nafai et al., (2017) and Qureshi et al., (2021). The decision to include English-only sources was made to ensure replicability of the search strategy to enhance the methodological strength of the review. It was noteworthy that very few Arabic-language sources were, in any event, found.

\section{CONCLUSION}

Telerehabilitation is an emerging practice in MENA. Occupational therapists, physiotherapists and rehabilitation doctors are most commonly involved. The limited research evidence available suggests that telerehabilitation is implemented predominantly in the home for patient health conditions and technology platforms that reflect practitioner or provider specialisation. Only one of the top four NCD mortality related conditions in MENA have evidence of telerehabilitation use. Interventions achieve statistically significant outcomes and patients are generally satisfied about their experience or positive about the idea of telerehabilitation. Rehabilitation professionals too are positive, but as yet most have scant experience and 
there are general rehabilitation workforce shortages with services centralised and a lack of community-based programs that create existing pressures on practitioners.

The research evidence in this review suggests implementation of telerehabilitation in MENA is feasible, acceptable to patients, and relevant to a range of professions and health conditions. The challenge is not whether telerehabilitation can be done in MENA, but how it can be done at scale so that more rehabilitation services are available, and patients have more efficient access to services.

Implementation and uptake of telerehabilitation requires readiness in regulatory and policy systems, capacity and security in technological infrastructure, confidence and competence of rehabilitation professionals and acceptance by patients and their families of this method of service delivery. While this review provides a starting point for an evidence-based approach to understanding telerehabilitation in MENA, continued research effort is required to support managers and policy makers, practitioners, and patients to consider when, how, and where to adopt this approach to service delivery and ensure its relevance and effectiveness.

\section{DECLARATIONS}

The authors declare no conflicts of interest. NQA was supported by a doctoral studies scholarship from Taibah University. The study forms part of his doctoral program. No other funding is declared.

\section{CORRESPONDING AUTHOR}

Naif Qasam Turabi Aljabri, College of Medical Rehabilitation Sciences, Taibah University, Saudi Arabia, Janadah Bin Umayyah Road، Tayba, Medina 42353, Saudi Arabia; nqjabri@taibahu.edu.sa

\section{REFERENCES}

Abolghasemian, M., Ebrahimzadeh, M. H., Enayatollahi, M., Honarmand, K., Kachooei, A. R., Mehdipoor, S., Mortazavi, M. J., Mousavian, A., Parsa, A., Akasheh, G., Bagheri, F., Ebrahimpour, A., Fakoor, M., Moradi, R., \& Razi, M. (2020). Iranian Orthopedic Association (IOA) response guidance to COVID-19 pandemic. Archives of Bone and Joint Surgery, 8(Suppl 1), $209-217$. https://doi.org/10.22038/ABJS.2020.47678.2370

Agostini, M., Moja, L., Banzi, R., Pistotti, V., Tonin, P., Venneri, A., \& Turolla, A. (2015). Telerehabilitation and recovery of motor function: A systematic review and meta-analysis. Journal of Telemedicine and Telecare, 21(4), 202-213. https://doi.org/10.1177/1357633X15572201

Alasfour, M., \& Almarwani, M. (2020). The effect of innovative smartphone application on adherence to a home-based exercise programs for female older adults with knee osteoarthritis in Saudi Arabia: A randomized controlled trial. Disability and Rehabilitation, 1-8. https://doi.org/10.1080/09638288.2020.1836268

Aloyuni, S., Alharbi, R., Kashoo, F., Alqahtani, M., Alanazi, A., Alzhrani, M., \& Ahmad, M. (2020). Knowledge, attitude, and barriers to telerehabilitation-based physical therapy practice in Saudi Arabia. Healthcare, 8(4), 460. https://doi.org/10.3390/healthcare8040460

Alqahtani, M. (2019). Preliminary analysis of perception, knowledge and attitude of home health patients using tele rehabilitation in Riyadh, Saudi Arabia. Bioscience Biotechnology Research Communications, 12(2), 309-316. https://doi.org/10.21786/bbrc/12.2/13

Azma, K., RezaSoltani, Z., Rezaeimoghaddam, F., Dadarkhah, A., \& Mohsenolhosseini, S. (2018). Efficacy of tele-rehabilitation compared with office-based physical therapy in patients with knee osteoarthritis: A randomized clinical trial. Journal of Telemedicine and Telecare, 24(8), 560-565. https://doi.org/10.1177/1357633X17723368

Barlev, L., Keren-Avraham, Y., Heber, I., \& Admon-Rik, G. (2015). People with disabilities in Israel 2015. State of Israel, Ministry of Justice, Commission for equal rights of persons with disabilities. https://brookdale-web.s3.amazonaws.com/uploads/2018/01/book-eng.pdf

Benjadid, M.S. (2019). 7.5 The organizations of physical and rehabilitation medicine in the world: The scope of physical and rehabilitation medicine in the Middle East and North Africa. Journal of the International Society of Physical and Rehabilitation Medicine, 2(Suppl. S1), 148-155. https:// 10.4103/jisprm.jisprm_34_19

Bonnechère, B., Van Vooren, M., Jansen, B., Van Sint, J.S., Rahmoun, M., \& Fourtassi, M. (2017). Patients' acceptance of the use of serious games in physical rehabilitation in Morocco. Games for Health, 6(5), 290-294. https://doi.org/10.1089/g4h.2017.0008 
Brennan, D. M., Mawson, S., \& Brownsell, S. (2009). Telerehabilitation: Enabling the remote delivery of healthcare, rehabilitation, and selfmanagement. Advanced Technologies in Rehabilitation - Studies in Health Technology and Informatics, 145, 231-248. https://doi.org/10.3233/978-1-60750-018-6-231

Brennan, D., Tindall, L., Theodoros, D., Brown, J., Campbell, M., Christiana, D., Smith, D., Cason, J., \& Lee, A. (2010). A blueprint for telerehabilitation guidelines. International Journal of Telerehabilitation, 2(2), 31-34. https://doi.org/10.5195/ijt.2010.6063

Bright, T., Wallace, S., \& Kuper, H. (2018). A systematic review of access to rehabilitation for people with disabilities in low-and middle-income countries. International Journal of Environmental Research and Public Health, 15(10), 2165. https://doi.org/10.3390/ijerph15102165

Critical Appraisal Skills Programme. (2018). CASP (Cohort study) Checklist. https://casp-uk.b-cdn.net/wp-content/uploads/2018/03/CASPCohort-Study-Checklist-2018 fillable form.pdf

Critical Appraisal Skills Programme. (2020). CASP (Randomised Controlled Trial) Checklist. https://casp-uk.b-cdn.net/wpcontent/uploads/2020/10/CASP RCT Checklist PDF Fillable Form.pdf

Cusick, A., \& Hamed El Sahly, R.M. (2018). People with disability in Libya are a medicalised minority: Findings of a scoping review. Scandinavian Journal of Disability Research, 20(1), 182-196. https://doi.org/10.16993/sjdr.2

Ferrer-Roca, O., \& Sosa ludicissa, M.C. (1999). Handbook of Telemedicine. Amsterdam, NY: IOS Press. Golebowicz, M., Levanon, Y., Palti, R., \& Ratzon, N.Z. (2015). Efficacy of a telerehabilitation intervention programme using biofeedback among computer operators. Ergonomics, 58(5), 791-802. https://doi.org/10.1080/00140139.2014.982210

Human Rights Watch. (2014). One billion forgotten: Protecting the human rights of persons with disabilities. 2014. https://www.hrw.org/sites/default/files/related material/2014\%20disabilities program low.pdf

Human Rights Watch. (2020). Middle East and North Africa. https://www.hrw.org/middle-east/n-africa

Hung, K.N.G., \& Fong, K.N. (2019). Effects of telerehabilitation in occupational therapy practice: A systematic review. Hong Kong Journal of Occupational Therapy, 32(1), 3-21. https://doi.org/10.1177/1569186119849119

Jafni, T.I., Baharu, M., Ismail, W., \& Hanafi, M.H. (2019). Exploring barriers that affect telerehabilitation readiness: A case study of rehabilitation centre in Malaysia. In: Saeed, F., Gazem, M., Mohammed, F. \& Busalim, A. (eds). Recent trends in data science and soft computing. IRT 2018. Advanced in Intelligent Systems and Computing Vol 843. Springer, Cham. https://doiorg.ezproxy.library.sydney.edu.au/10.1007/978-3-319-99007-1_70

Kalron, A., Tawil, H., Peleg-Shani, S., \& Vatine, J.J. (2018). Effect of telerehabilitation on mobility in people after hip surgery: A pilot feasibility study. International Journal of Rehabilitation Research, 41(3), 244-250. https://doi.org/10.1097/MRR.0000000000000296

Kaneda T. \& El-Saharty, S. (2017). Curbing the noncommunicable disease epidemic in the Middle East and North Africa: Prevention among young people is the key, Population Reference Bureau. Washington, DC: Population Reference Bureau.

Kargar, N., Deldar K, Ahmadabadi A, Froutan R, \& Mazlom S.R. (2020). Can a self-care educational mobile application improve the quality of life of victims with hand burns? A randomized controlled trial. Crescent Journal of Medical and Biological Sciences, 7(4):497-502.

Kizony, R., Weiss, P. L., Harel, S., Feldman, Y., Obuhov, A., Zeilig, G., \& Shani, M. (2017). Tele-rehabilitation service delivery journey from prototype to robust in-home use. Disability and Rehabilitation, 39(15), 1532-1540. https://doi.org/10.1080/09638288.2016.1250827

Langbecker, D., Caffery, L. J., Gillespie, N., \& Smith, A. C. (2017). Using survey methods in telehealth research: A practical guide. Journal of Telemedicine and Telecare, 23(9), 770-779. https://doi.org/10.1177/1357633X17721814

Laver, K. E., Adey-Wakeling, Z., Crotty, M., Lannin, N. A., George, S. \& Sherrington, C. (2020). Telerehabilitation services for stroke. Cochrane Library, 2020(1). https://doi.org/10.1002/14651858.CD010255.pub3

McCue, M., Fairman, A., \& Pramuka, M. (2010). Enhancing quality of life through telerehabilitation. Physical Medicine and Rehabilitation Clinics of North America, 21(1), 195-205. https://doi.org/10.1016/j.pmr.2009.07.005

Mclntyre, M., Robinson, L.R., \& Mayo, A. (2020). Practical considerations for implementing virtual care in physical medicine and rehabilitation: For the pandemic and beyond. American Journal of Physical Medicine \& Rehabilitation, 99(6), 464-467. https://doi.org/10.1097/PHM.0000000000001453

Meyer, T., Gutenbrunner, C., Bickenbach, J., Cieza, A., Melvin, J., \& Stucki, G. (2011). Towards a conceptual description of rehabilitation as a health strategy. Journal of Rehabilitation Medicine, 43(9), 765-769. https://doi.org/10.2340/16501977-0865

Ministry of Health. (2013). National E- Health Strategy. https://www.moh.gov.sa/en/Ministry/nehs/Pages/Ehealth.aspx

Molini-Avejonas, D. R., Rondon-Melo, S., Amato, C. A., \& Samelli, A. G. (2015). A systematic review of the use of telehealth in speech, language and hearing sciences. Journal of Telemedicine and Telecare, 21(7), 367-376. https://doi.org/10.1177/1357633X15583215

Nabutovsky I, Ashri S, Nachshon A, Tesler R, Shapiro Y, Wright E, et al. (2020). Feasibility, safety, and effectiveness of a mobile application in cardiac rehabilitation. Israel Medical Association Journal, 22(6):357-63.

Nabutovsky, I., Nachshon, A., Klempfner, R., Shapiro, Y., \& Tesler, R. (2020). Digital cardiac rehabilitation programs: the future of patientcentered medicine. Telemedicine Journal and e-Health, 26(1), 34-41. https://doi.org/10.1089/tmj.2018.0302

Nafai, S., Barlow, K., \& Stevens-Nafai, E. (2017). OT in Morocco: Sustaining service-learning trips through telehealth. OT Practice, 22(2), 2022 
Niknejad, N., Ismail, W., Bahari M., \& Nazari, B. (2021). Understanding telerehabilitation technology to evaluate stakeholders' adoption of telerehabilitation services: A systematic literature review and directions for further research, Archives of Physical Medicine and Rehabilitation, 102 (7), 1390-1403. https://doi.org/10.1016/i.apmr.2020.12.014

Parmanto, B., Lewis, A.N., Graham, K., \& Bertolet, M.H. (2016). Development of the Telehealth Usability Questionnaire (TUQ). International Journal of Telerehabilitation, 8(1): 3-10. doi: 10.5195/ijt.2016.6196

Peretti, A., Amenta, F., Tayebati, S.K., Nittari, G., \& Mahdi, S.S. (2017). Telerehabilitation: Review of the state-of-the-art and areas of application. JMIR Rehabilitation and Assistive Technologies, 4(2), e7-e7. https://doi.org/10.2196/rehab.7511

Piron, L., Turolla, A., Tonin, P., Piccione, F., Lain, L., \& Dam, M. (2008). Satisfaction with care in post-stroke patients undergoing a telerehabilitation programme at home. Journal of Telemedicine and Telecare, 14(5), 257-260. https://doi.org/10.1258/itt.2008.080304

Qureshi, A. Z., Ullah, S., Aldajani, A. A., Basson, P., Al Habter, A. M., Ali, T., Almubark, B. M., Al Atwi, M., Al Ibrahim, F., Alsuhaibani, A., \& Al Jadid, M. S. (2021). Telerehabilitation guidelines in Saudi Arabia. Telemedicine Journal and e-Health. https://doi.org/10.1089/tmj.2020.0355

QSR International Pty Ltd. (2020) NVivo (released in March 2020), https://www.qsrinternational.com/nvivo-qualitative-data-analysissoftware/home

Reilly, R., Evans, K., Gomersall, J., Gorham, G., Peters, M.D.J., Warren, S., O'Shea, R., Cass, A., \& Brown, A. (2016). Effectiveness, cost effectiveness, acceptability and implementation barriers/enablers of chronic kidney disease management programs for Indigenous people in Australia, New Zealand and Canada: A systematic review of mixed evidence. BMC Health Services Research, 16(1), 119-119. https://doi.org/10.1186/s12913-016-1363-0

Rosen, B., Waitzberg, R., \& Merkur, S. (2015). Israel: health system review. Health Systems in Transition, 17(6), 1-212. PMID: 27050102

Sarfo, F.S., Ulasavets, U., Opare-Sem, O.K., \& Ovbiagele, B. (2018). Tele-rehabilitation after stroke: An updated systematic review of the literature. Journal of Stroke and Cerebrovascular Diseases, 27(9), 2306-2318. https://doi.org/10.1016/j.jstrokecerebrovasdis.2018.05.013

Sarsak, H.I. (2020). Telerehabilitation services: A successful paradigm for occupational therapy clinical services? International Physical Medicine \& Rehabilitation Journal, 5(2). http://dx.doi.org/10.15406/ipmri.2020.05.00237

Schutte, J., Gales, S., Filippone, A., Saptono, A., Parmanto, B., \& McCue, M. (2012). Evaluation of a telerehabilitation system for communitybased rehabilitation. International Journal of Telerehabilitation, 4(1), 15-32. https://doi.org/10.5195/IJT.2012.6092

Stucki, G., Cieza, A., \& Melvin, J. (2007). The International Classification of Functioning, Disability and Health: a unifying model for the conceptual description of the rehabilitation strategy. Journal of Rehabilitation Medicine, 39(4), 279-285. https://doi.org/10.2340/16501977-0041

Stucki, G., Reinhardt, J.D., \& Grimby, G. (2007). Organizing human functioning and rehabilitation research into distinct scientific fields. Part II: conceptual descriptions and domains for research. Journal of Rehabilitation Medicine, 39(4), 299-307. https://doi.org/10.2340/165019770051

Tenforde, A. S., Hefner, J. E., Kodish-Wachs, J. E., laccarino, M. A., \& Paganoni, S. (2017). Telehealth in physical medicine and rehabilitation: a narrative review. PM\&R: The Journal of Injury, Function and Rehabilitation, 9(5), S51-S58. https://doi.org/10.1016/i.pmri.2017.02.013

The Joanna Briggs Institute. (2013). Critical appraisal tools. https://jbi.global/critical-appraisal-tools

Thompson, S. (2017). Disability prevalence and trends. K4D Helpdesk Report. Brighton, UK: Institute of Development Studies. https://opendocs.ids.ac.uk/opendocs/handle/20.500.12413/13237

Torsney, K. (2003). Advantages and disadvantages of telerehabilitation for persons with neurological disabilities. NeuroRehabilitation, 18(2), 183-185. https://doi.org/10.3233/NRE-2003-18211

Ullah, S., Maghazil, A.M., Qureshi, A.Z., Tantawy, S., Moukais, I.S., \& Aldajani, A.A. (2020). Knowledge and attitudes of rehabilitation professionals toward telerehabilitation in Saudi Arabia: A cross-sectional Survey. Telemedicine Journal and e-Health, 27(5), 587-591. https://doi: 10.1089/tmj.2020.0016

United Nations Economic and Social Commission for Western Asia (2018). Disability in the Arab region 2018. https://www.unescwa.org/publications/disability-arab-region-2018

United Nations Statistics Division (2020). Methodology: Standard country or area codes for statistical use (M49): Developing regions. https://unstats.un.org/unsd/methodology/m49/

Vision 2030 Kingdom of Saudi Arabia. (2016). National Transformation Program. https://vision2030.gov.sa/en/programs/NTP

World Federation of Occupational Therapists [WFOT] (2021) Position Statement: Occupational Therapy and Telehealth, WFOT, Retrieved, https://wfot.org/resources/occupational-therapy-and-telehealth

World Health Organization, United Nations Children's Fund. (2018). Global Conference on Primary Health Care: from Alma-Ata towards universal health coverage and the Sustainable Development Goals, Astana, Kazakhstan, 25 and 26 October 2018. https://www.who.int/docs/default-source/primary-health/declaration/gcphc-declaration.pdf

World Health Organization. (2010). Opportunities and developments in Member States: Report on the second global survey on eHealth. https://www.who.int/goe/publications/goe telemedicine 2010.pdf 
World Health Organization. (2016). Atlas of eHealth country profiles: The use of eHealth in support of universal health coverage: based on the findings of the third global survey on eHealth 2015. https://www.who.int/publications/i/item/9789241565219

World Health Organization. (2017). Rehabilitation in health systems. [Reissued 2019 with editorial corrections] https://www.who.int/publications/i/item/9789241515986

World Health Organization. (2017). Global diffusion of eHealth: Making universal health coverage achievable: Report of the third global survey on eHealth. https://www.who.int/ehealth/en/

World Health Organization. (2020). Rehabilitation. https://www.who.int/news-room/fact-sheets/detail/rehabilitation

World Health Organization. (2011). World report on disability 2011. https://www.who.int/disabilities/world report/2011/report.pdf

World Physiotherapy. (2019) Report of the World Physiotherapy/ INPTRA Digital Physical Therapy Practice Task Force, London, UK, World Physiotherapy. ISBN: 978-1-914952-11-1

Zahid, Z., Atique, S., Saghir, M.H., Ali, I., Shahid, A., \& Malik, R.A. (2017). A Commentary on telerehabilitation services in Pakistan: Current trends and future possibilities. International Journal of Telerehabilitation, 9(1), 71-76. https://doi.org/10.5195/ijt.2017.6224

Ziadé, N., el Kibbi, L., Hmamouchi, I., Abdulateef, N., Halabi, H., Hamdi, W., Abutiban, F., el Rakawi, M., Eissa, M., \& Masri, B. (2020). Impact of the COVID-19 pandemic on patients with chronic rheumatic diseases: A study in 15 Arab countries. International Journal of Rheumatic Diseases, 11, 1550-1557. https://doi.org/10.1111/1756-185X.13960 


\section{APPENDIX}

\section{MEDLINE VIA (OVID INTERFACE): $\operatorname{RESULT}(N=6)$}

1 telehealth.mp. or Telemedicine/

2 tele-health.mp.

3 telemedicine.mp.

4 tele-medicine.mp.

5 telerehabilitation.mp. or Telerehabilitation/

6 tele-rehabilitation.mp.

7 ehealth.mp.

8 e-health.mp.

9 rehabilitation.mp. or Rehabilitation/

10 habilitation.mp.

11 middle east/ or bahrain/ or iran/ or iraq/ or israel/ or jordan/ or kuwait/ or lebanon/ or oman/ or qatar/ or saudi arabia/ or syria/ or united arab emirates/ or yemen/ (102498)

12 Palestine.mp.

13 africa, northern/ or algeria/ or egypt/ or libya/ or morocco/ or tunisia/ or mauritania/

14 "western sahara".mp.

15 "mobile health".mp.

16 mhealth.mp.

171 or 2 or 3 or 4 or 5 or 6 or 7 or 8 or 15 or 16

189 or 10

1911 or 12 or 13 or 14

2017 and 18 and 19

21 limit 20 to $y r=" 1990-2020 "$

Allied and Complementary Medicine Database (AMED): Result ( $N=2)$, Excerpta Medica Database (EMBASE): Result ( $N=24)$, Joanna Briggs Institute (JBI) EBP Database: Result $(N=0)$ AND The Cochrane Database of Systematic Reviews (CDSR): Result ( $N=0)$; Same as Medline above via (OVID interface).

Scopus: a comprehensive database for scientific, technical and medical information (Scopus web interface): $R e s u l t(N=36)$

( ( ( TITLE-ABS-KEY ( telehealth ) OR TITLE-ABS-KEY ( telehealth )) AND PUBYEAR > 1989 AND PUBYEAR < 2021) OR ( ( TITLE-ABS-KEY ( telemedicine ) OR TITLE-ABSKEY (tele-medicine )) AND PUBYEAR > 1989 AND PUBYEAR < 2021 ) OR ( ( TITLE-ABS-

KEY ( telerehabilitation ) OR TITLE-ABS-KEY ( telerehabilitation )) AND PUBYEAR > 1989 AND PUBYEAR < 2021 ) OR ( ( TITLE-ABS-KEY ( ehealth ) OR TITLE-ABS$\operatorname{KEY}($ e-health )) AND PUBYEAR > 1989 AND PUBYEAR < 2021 )) OR ( (TITLE-ABS-KEY ( "mobile health" ) OR TITLE-ABS-KEY ( mhealth )) AND PUBYEAR > 1989 AND PUBYEAR < 2021))

AND ( ( TITLE-ABS-KEY ( rehabilitation ) OR TITLE-ABS-

KEY ( habilitation )) AND PUBYEAR > 1989 AND PUBYEAR $<2021$ ) 
AND ( ( ( TITLE-ABS-KEY ( "middle east" OR bahrain OR qatar OR "United Arab

Emirates" OR yemen OR iran OR iraq OR israel ) OR TITLE-ABS-

KEY ( jordan OR kuwait OR lebanon OR oman OR syria OR "Saudi

Arabia" OR palestine )) AND PUBYEAR > 1989 AND PUBYEAR < 2021 ) OR ( TITLE-ABS-KEY ( "North

Africa" OR tunisia OR egypt OR morocco OR "Western

Sahara" OR algeria OR libya OR mauritania) AND PUBYEAR > 1989 AND PUBYEAR < 2021))

CINAHL: Cumulative Index to Nursing \& Allied Health Literature via (EbscoHost): Result (N=17)

S1. (MH "Telehealth+") OR "telehealth OR tele-health"

S2. (MH "Telemedicine+") OR "telemedicine"

S3. "tele-medicine"

S4. (MH "Telerehabilitation")

S5. "tele-rehabilitation"

S6. "ehealth"

S7. "e-health"

S8. "'mobile health"'

S9. "mhealth"

S10. S1 OR S2 OR S3 OR S4 OR S5 OR S6 OR S7 OR S8 OR S9

S11. (MH "Rehabilitation+") OR "rehabilitation"

S12. "habilitation"

S13. S11 OR S12

S14. (MH "Yemen") OR (MH "United Arab Emirates") OR (MH "Syria") OR (MH "Saudi Arabia") OR (MH "Qatar") OR (MH "Oman") OR (MH "Lebanon") OR (MH "Kuwait") OR (MH "Jordan") OR (MH "Israel") OR (MH "Iraq") OR (MH "Iran") OR (MH "Bahrain") OR (MH "Middle East+")

S15. "palestine"

S 16. (MH "Africa, Northern+") OR (MH "Algeria") OR (MH "Egypt") OR (MH "Libya") OR (MH "Morocco") OR (MH "Tunisia") OR (MH "Mauritania") OR "( "north africa" OR Tunisia OR Egypt OR Morocco ) OR ( Algeria OR Libya OR Mauritania OR "western Sahara" )"

\section{S 17. S14 OR S15 OR S16}

S 18. S10 AND S13 AND S17

S 19. S10 AND S13 AND S17 (Limiters - Published Date: 19900101-20201231)

Web of Sciences (WoS): Result $(\mathrm{N}=20)$

\# 1 TOPIC: (telehealth) OR TOPIC: (tele-health)

Indexes $=S C I-E X P A N D E D, S S C I, A \& H C l, C P C I-S, C P C I-S S H, E S C I, C C R-E X P A N D E D, I C$ Timespan=1990-2020

\# 2 TOPIC: (telemedicine) OR TOPIC: (tele-medicine)

Indexes=SCI-EXPANDED, SSCI, A\&HCI, CPCI-S, CPCI-SSH, ESCI, CCR-EXPANDED, IC Timespan=1990-2020 
\# 3 TOPIC: (telerehabilitation) OR TOPIC: (tele-rehabilitation)

Indexes=SCI-EXPANDED, SSCI, A\&HCI, CPCI-S, CPCI-SSH, ESCI, CCR-EXPANDED, IC Timespan=1990-2020

\# 4 TOPIC: (ehealth) OR TOPIC: (e-health)

Indexes=SCI-EXPANDED, SSCI, A\&HCI, CPCI-S, CPCI-SSH, ESCI, CCR-EXPANDED, IC Timespan=1990-2020

\# 5 TOPIC: ("mobile health") OR TOPIC: (mhealth)

Indexes=SCI-EXPANDED, SSCI, A\&HCI, CPCI-S, CPCI-SSH, ESCI, CCR-EXPANDED, IC Timespan=1990-2020

\# 6 TOPIC: ("Middle East" OR Bahrain OR Qatar OR "United Arab Emirates" OR Yemen) OR TOPIC: (Iran OR Iraq OR Israel OR Jordan OR Kuwait OR Lebanon) OR TOPIC: (Oman OR Syria OR "Saudi Arabia" OR Palestine)

Indexes=SCI-EXPANDED, SSCI, A\&HCI, CPCI-S, CPCI-SSH, ESCI, CCR-EXPANDED, IC Timespan=1990-2020

\# 7 TOPIC: ("North Africa" OR Tunisia OR Egypt OR Morocco OR "Western Sahara") OR TOPIC: (Algeria OR Libya OR Mauritania)

Indexes=SCI-EXPANDED, SSCI, A\&HCI, CPCI-S, CPCI-SSH, ESCI, CCR-EXPANDED, IC Timespan=1990-2020

\# 8 TOPIC: (rehabilitation) OR TOPIC: (habilitation)

Indexes=SCI-EXPANDED, SSCI, A\&HCl, CPCI-S, CPCI-SSH, ESCI, CCR-EXPANDED, IC Timespan=1990-2020

\# 9 \#5 OR \#4 OR \#3 OR \#2 OR \#1

Indexes=SCI-EXPANDED, SSCI, A\&HCI, CPCI-S, CPCI-SSH, ESCI, CCR-EXPANDED, IC Timespan=1990-2020

\# 10 \#7 OR \#6

Indexes=SCI-EXPANDED, SSCI, A\&HCI, CPCI-S, CPCI-SSH, ESCI, CCR-EXPANDED, IC Timespan=1990-2020

\# 11 \#10 AND \#9 AND \#8

Indexes=SCI-EXPANDED, SSCI, A\&HCI, CPCI-S, CPCI-SSH, ESCI, CCR-EXPANDED, IC Timespan=1990-2020

\footnotetext{
(c) (1) This work is licensed under a Creative Commons Attribution 4.0 International License. 